\title{
Microbiological and Immunological Markers in Milk and Infant Feces for Common Gastrointestinal Disorders: A Pilot Study
}

\author{
Marina Aparicio ${ }^{1}$, Claudio Alba ${ }^{2}$, Proctocolitis Study Group of CAM Public Health Area $6^{3}$, \\ Juan Miguel Rodríguez ${ }^{1}$ (D) and Leonides Fernández ${ }^{2, *(\mathbb{D})}$ \\ 1 Department of Nutrition and Food Science, Complutense University of Madrid, 28040 Madrid, Spain; \\ marinaap@ucm.es (M.A.); jmrodrig@vet.ucm.es (J.M.R.) \\ 2 Department of Galenic Pharmacy and Food Technology, Complutense University of Madrid, \\ 28040 Madrid, Spain; claudioalbarubio@gmail.com \\ 3 EAP Valle de la Oliva, Majadahonda, 28220 Madrid, Spain; enriqueta.roman@salud.madrid.org \\ * Correspondence: leonides@ucm.es; Tel.: +34-91-3943745
}

Received: 31 December 2019; Accepted: 20 February 2020; Published: 27 February 2020

\begin{abstract}
The objective of this pilot study was to assess the fecal microbiome and different immunological parameters in infant feces and maternal milk from mother-infant pairs in which the infants were suffering from different gastrointestinal disorders (colic, non-IgE-mediated cow milk protein allergy (CMPA), and proctocolitis). A cohort of 30 mother-infant pairs, in which the infants were diagnosed with these gastrointestinal disorders or included as healthy controls, were recruited. Bacterial composition of infant feces and breast milk was determined by metataxonomic sequencing. Immunological compounds were quantified using multiplexed immunoassays. A higher abundance of Eggerthellaceae, Lachnospiraceae and Peptostreptococcaceae, and lower abundance of Bifidobacterium and higher abundance of Rothia were registered in fecal samples from the CMPA group. Eggerthellaceae was also significantly more abundant in milk samples of the CMPA group. There were no differences in the concentration of immunological compounds in infant fecal samples between the four groups. In contrast, differences were found in the concentration and/or frequency of compounds related to acquired immunity and granulocyte colony stimulating factor (GCSF) in breast milk samples. In conclusion, a few microbial signatures in feces may explain part of the difference between CMPA and other infants. In addition, some milk immunological signatures have been uncovered among the different conditions addressed in this pilot study.
\end{abstract}

Keywords: human milk; infant feces; microbiome; immunology; intestinal diseases; colic; non-IgEmediated allergy; proctocolitis; pilot study

\section{Introduction}

Infant gastrointestinal disorders are defined as different combinations of chronic or recurrent gastrointestinal signs and symptoms that usually do not correspond to structural or biochemical disorders [1]. Gastrointestinal disorders occur in a high proportion of the infants and are a common source of infant and parental discomfort as they lead to reiterated visits to the pediatrician, at either the primary care or hospital level, and frequent and unsuccessful changes in infant feeding practices [2]. The term includes diverse disorders, such as colic, non-IgE-mediated allergies and proctocolitis.

Infantile colic is defined as infant paroxysms of inconsolable crying and/or fussing for more than three hours per day, more than three days per week [3]. This condition involves several gastrointestinal factors, such as intestinal immaturity, hypermotility secondary to a presumed autonomic imbalance and alterations in the fecal microbiome [4]. Moreover, it increases the probability of suffering from 
psychosocial distress and depression, negatively affecting the maternal-child bond [5,6]. Non- $\operatorname{IgE}$ mediated food allergy has also emerged as a frequent disease in recent years, involving cellular immunity and mainly affecting the digestive tract [7]. This disorder is characterized by subacute and/or chronic non-specific symptoms that appear gradually (from one hour to several days after contact with the antigen), and include abdominal colicky pain, inappetence, pathological gastroesophageal reflux, blood in stools, diarrhea, constipation and, less frequently, enteropathy with poor weight gain [4]. Cow's milk protein allergy (CMPA) is the most prevalent type of food allergy in infancy, and its incidence during first year of life has been estimated to be $2 \%$ to $7.5 \%$ [8]. Proctocolitis accounts for up to $64 \%$ of rectal bleeding in the infant, and CMPA or lactose intolerance plays a major role in its development [9]. It is one of the most frequent food allergies but these children do not show signs of systemic involvement (vomiting, diarrhea, fever or growth disorders), which separates this disorder from other manifestations of allergy [4]. Unfortunately, the pathogenesis of the conditions cited above is still poorly understood [10] and they usually share some symptoms; consequently, the differential diagnosis remains a challenge.

Alterations in both the innate immune system and the intestinal microbiota, which play an important role in the development of intestinal tolerance, seem to be involved in these conditions [11-13], but their potential link is still far from elucidated. The mature gastrointestinal tract is typically an effective barrier to prevent intact ingested food antigens from stimulating the immune system. However, this barrier is immature in newborns and these intact antigens are able to permeate the intestinal wall and induce an immune response [14]. The intestinal microbiota plays a crucial role in the development of the immune response of the intestinal mucosa and alterations in the early gut microbiota may precede the development of allergies [13] as well as the acquisition of oral tolerance [15]. Human milk also plays a key role in shaping the gut microbiota of infants because it provides a continuous source of commensal microorganisms and some compounds that act as prebiotics $[16,17]$. Therefore, gut microbiota could be both a relevant target for innovative therapeutic strategies in children with gastrointestinal disorders and a source of simple and non-invasive markers for these conditions.

In this context, the objective of this work was, first, to assess the microbiome and a wide spectrum of immunological parameters in maternal milk and infant feces from groups of mother-infant pairs in which the infants were suffering from any of the different gastrointestinal disorders described above. Secondly, to elucidate if there are immunological or microbiological condition-specific signatures.

\section{Materials and Methods}

\subsection{Participants}

A cohort of 30 mother-infant pairs, in which the respective infants were diagnosed with colic $(n=12)$, non-IgE mediated CMPA $(n=5)$, proctocolitis $(n=5)$, or included as healthy controls $(n=8)$, were recruited in this pilot study (Table 1). In accordance with the Declaration of Helsinki, all volunteers, parents or legal tutors gave written informed consent to the protocol, which had been approved (protocol 10/2015) by the Norwest Local Ethical Committee of Clinical Research of Servicio Madrileño de Salud (Madrid, Spain). Case definitions, inclusion and exclusion criteria, and the main characteristics of the recruited infants are shown in Table 1. 
Table 1. Demographic and clinical characteristics of the four groups of participating infants $(N=30)$, including case definition and inclusion and exclusion criteria.

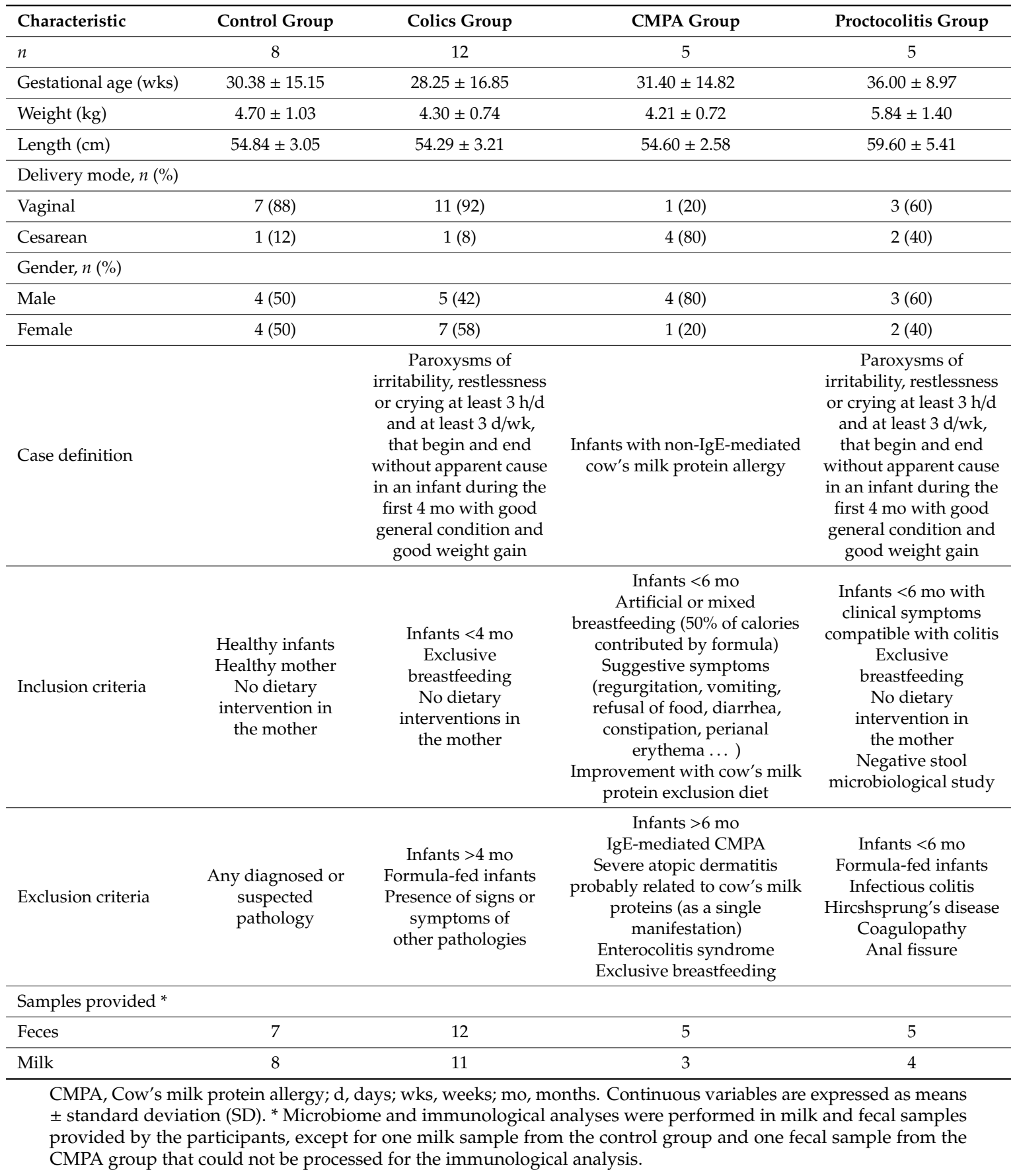

\subsection{Collection of the Samples}

Milk and infant fecal samples were collected as previously described [18], and stored at $-20{ }^{\circ} \mathrm{C}$ in the Primary Health centers. Samples were shipped in temperature-controlled containers to the Complutense University of Madrid for the subsequent analysis.

\subsection{DNA Extraction from the Samples}

Approximately $1 \mathrm{~g}$ of fecal or milk sample from each infant or mother, respectively, was used for DNA extraction following the methods described previously [18]. Extracted DNA was eluted in $22 \mu \mathrm{L}$ of nuclease-free water and stored at $-20^{\circ} \mathrm{C}$ until further analysis. Purity and concentration of 
each extracted DNA sample was estimated using a NanoDrop 1000 spectrophotometer (NanoDrop Technologies, Inc., Rockland, USA). Negative controls were added (blanks) during the extraction.

\subsection{PCR Amplification and Sequencing}

The analysis of the microbiome was carried out using the technique of massive sequencing of the 16S rDNA gene through the MiSeq system of Illumina (Parque Cientifico de Madrid), with the universal primers S-D-Bact-0341-b-S-17 (CCTACGGGNGGCWGCAG) and S-D-Bact-129 0785-a-A-21 (GACTACHVGGGTATCTAATCC) directed to the V3-V4 hypervariable regions of the 16S rDNA [19]. In the second PCR-reactions, forward and reverse sequences were separated by barcodes appended to $3^{\prime}$ and $5^{\prime}$ terminal ends of the PCR amplicons. The concentration of DNA for each sample was measured by the 2100 Bioanalyzer system (Agilent, Santa Clara, CA, USA). PCR products were pooled at around equimolar DNA concentrations. The band that had the correct size after running on the agarose gel, was excised and purified by using a QIAEX II Gel Extraction Kit (Qiagen) and then quantified with PicoGreen (BMG Labtech, Jena, Germany). The pooled, purified and barcoded DNA amplicons were sequenced by using the Illumina MiSeq pair-end protocol (Illumina Inc., San Diego, CA, USA) following the manufacturer's protocols at the facilities of Parque Científico de Madrid (Tres Cantos, Spain). Negative extraction control was used in PCR reactions and their products were not sequenced after not showing visible bands in the electrophoresis ( $1 \%$ agarose gel). The Illumina reads or amplified fragments (forward and reverse) were combined into single reads by using SeqPrep (https://github.com/jstjohn/SeqPrep) with a limit of 0.5 mismatched bases. After quality control, the reads were assembled and the resulting sequences were processed by using QIIME package version 1.9.1 $[20,21]$ and classified taxonomically into operational taxonomic units (OTUs) by comparison with the SILVA SSU database (version 132) [22] using a Naïve-Bayes classification method.

\subsection{Immunological Assays}

Fecal samples (approximately $0.1 \mathrm{~mL}$ ) were suspended in PBS $(1: 10 \mathrm{w} / \mathrm{v})$ and homogenized. Supernatants collected after centrifugation $\left(14,000 \times g, 15 \mathrm{~min}, 4{ }^{\circ} \mathrm{C}\right)$ were used for determination of cytokines, chemokines and growth factors in duplicate by the BioPlex system (BioRad), using the Human Cytokine, Chemokine and Growth Factor Assays kit as described previously [23]. These include: interleukins (IL) $1 \beta, 2,4,5,6,7,8,10,12$ (p70), 13 and 17, interferon-gamma (IFN $\gamma$ ), granulocyte colony stimulating factor (GCSF), granulocyte-macrophage colony stimulating factor (GMCSF), monocyte chemoattractant protein-1 (MCP1), macrophage inflammatory protein-1 $\beta$ (MIP1 $\beta$ ) and tumor necrosis factor-alpha $(\mathrm{TNF} \alpha)$. Standard curves were performed for each analyte. Centrifugation $(800 \times g, 15 \mathrm{~min}$, $4{ }^{\circ} \mathrm{C}$ ) was used to remove the fat layer and suspended material from milk samples. The intermediate aqueous layer was collected for determination of the same immunological compounds.

\subsection{Statistical and Bioinformatic Analysis}

Normally distributed quantitative data were expressed as the mean and $95 \%$ confidence interval (CI) of the mean. When not normally distributed, the data were presented as the median and interquartile range (IQR). Kruskal-Wallis tests were used to evaluate the differences in the median concentration of the immunological compounds and in the median relative abundances of dominant taxa, followed by Dunn's tests to identify which levels of the independent variable differ from each other level. Fisher's exact tests or the Freeman-Halton extension of the Fisher exact probability test for a $2 \times 4$ contingency table were performed to compare the frequency of detection of different bacterial genera and immunological compounds.

LefSe analysis (LDA effect size) was used to identify differences in taxonomy between the study groups [21]. The richness and diversity of the milk and fecal microbiota were determined by calculating the Shannon diversity index, which takes into account the number and evenness of the bacterial species. Microbiota community differences between samples (beta diversity) were tested by permutational multivariate analysis of variance (PERMANOVA) comparison of unweighted UNIFRAC distance 
matrices, with 999 permutations. Spearman rank correlation was performed to evaluate possible correlations between different factors of study (R package: corrplot). Agglomerative or cluster-merging hierarchical clustering was performed by using the Euclidean distance and complete hclust_method methods ( $\mathrm{R}$ package: heatmaply) to analyze the binary matrix of detection of the immune factors evaluated in the study. Afterwards, a heatmap was constructed including the detection of the immune factors in the different sample types and the sample description, as well as colored bars vector to classify the samples in the different study groups. All analyses were performed with the R software version 3.3.2 (R-project, http://www.r-project.org).

\section{Results}

\subsection{Metataxonomic Profiling of the Fecal Samples}

The most frequently detected and abundant genus in the fecal samples was Bifidobacterium, which was present in nearly all the samples ranging from a median (IQR) relative abundance of $64.24 \%$ $(61.91 \%-75.05 \%)$ in the control group to $23.40 \%(5.27 \%-51.23 \%)$ in the CMPA group (Table 2 and Figure 1a). Escherichia-Shigella, Streptococcus and Lactobacillus were also detected in $>50 \%$ of the samples (Table 2 and Figure 1a). No differences were observed with regard to the frequency of detection or concentration of the most abundant bacterial phyla between groups (results not shown). However, at the family level, the concentration of Eggerthellaceae, Lachnospiraceae and Peptostreptococcaceae was higher in fecal CMPA samples than in those from other groups (Figure 1b). At the genus level, when comparing groups by pairs, lower abundance of Bifidobacterium and higher abundance of Rothia was the main feature of the CMPA group in comparison with the other three groups. Moreover, Erysipelatoclostridium abundance was higher in controls and Intestinibacter was higher in the proctocolitis group followed by the CMPA one (Figure 1c). 
Table 2. Frequency and relative abundance of operational taxonomic units at genus level in fecal samples from participants $(N=29)$ in each group of study: control, colic, cow's milk protein allergy (CMPA), and proctocolitis.

\begin{tabular}{|c|c|c|c|c|c|c|c|c|c|c|}
\hline \multirow[b]{2}{*}{$\begin{array}{l}\text { Phylum } \\
\text { Genus }\end{array}$} & \multicolumn{2}{|c|}{$\begin{array}{c}\text { Control Group } \\
\quad(n=7)\end{array}$} & \multicolumn{2}{|c|}{$\begin{array}{l}\text { Colic Group } \\
\quad(n=12)\end{array}$} & \multicolumn{2}{|c|}{$\begin{array}{l}\text { CMPA Group } \\
\quad(n=5)\end{array}$} & \multicolumn{2}{|c|}{$\begin{array}{l}\text { Proctocolitis Group } \\
\qquad(n=5)\end{array}$} & \multirow[b]{2}{*}{$p^{*}$} & \multirow[b]{2}{*}{$p^{* *}$} \\
\hline & $\begin{array}{c}n \\
(\%)\end{array}$ & $\begin{array}{l}\text { Median } \\
\text { (IQR) }\end{array}$ & $\begin{array}{c}n \\
(\%)\end{array}$ & $\begin{array}{l}\text { Median } \\
\text { (IQR) }\end{array}$ & $\begin{array}{c}n \\
(\%)\end{array}$ & $\begin{array}{l}\text { Median } \\
\text { (IQR) }\end{array}$ & $\begin{array}{c}n \\
(\%)\end{array}$ & $\begin{array}{l}\text { Median } \\
\text { (IQR) }\end{array}$ & & \\
\hline \multicolumn{11}{|l|}{ Actinobacteria } \\
\hline Bifidobacterium & $\begin{array}{c}6 \\
(86)\end{array}$ & $\begin{array}{c}64.24 \\
(61.91-75.05)\end{array}$ & $\begin{array}{c}12 \\
(100)\end{array}$ & $\begin{array}{c}62.10 \\
(39.57-88.63)\end{array}$ & $\begin{array}{c}4 \\
(80)\end{array}$ & $\begin{array}{c}23.40 \\
(5.27-51.23)\end{array}$ & $\begin{array}{c}5 \\
(100)\end{array}$ & $\begin{array}{c}54.14 \\
(37.49-77.62)\end{array}$ & 0.335 & 0.040 \\
\hline Collinsella & $\begin{array}{c}0 \\
(0)\end{array}$ & - & $\begin{array}{c}4 \\
(33)\end{array}$ & $\begin{array}{c}4.00 \\
(2.01-14.06)\end{array}$ & $\begin{array}{c}2 \\
(40)\end{array}$ & $\begin{array}{c}3.41 \\
(3.37-3.45)\end{array}$ & $\begin{array}{c}0 \\
(0)\end{array}$ & - & 0.178 & 1.000 \\
\hline \multicolumn{11}{|l|}{ Bacteroidetes } \\
\hline Bacteroides & $\begin{array}{c}4 \\
(57)\end{array}$ & $\begin{array}{c}2.78 \\
(0.54-5.52)\end{array}$ & $\begin{array}{c}8 \\
(67)\end{array}$ & $\begin{array}{c}0.45 \\
(0.22-4.29)\end{array}$ & $\begin{array}{c}0 \\
(0)\end{array}$ & - & $\begin{array}{c}4 \\
(80)\end{array}$ & $\begin{array}{c}1.27 \\
(0.70-3.61)\end{array}$ & 0.055 & 0.811 \\
\hline \multicolumn{11}{|l|}{ Firmicutes } \\
\hline Enterococcus & $\begin{array}{c}5 \\
(71)\end{array}$ & $\begin{array}{c}0.97 \\
(0.95-1.37)\end{array}$ & $\begin{array}{c}8 \\
(67)\end{array}$ & $\begin{array}{c}0.33 \\
(0.20-1.69)\end{array}$ & $\begin{array}{c}3 \\
(60)\end{array}$ & $\begin{array}{c}0.42 \\
(0.27-1.42)\end{array}$ & $\begin{array}{c}5 \\
(100)\end{array}$ & $\begin{array}{c}3.28 \\
(2.27-3.29)\end{array}$ & 0.552 & 0.300 \\
\hline Lactobacillus & $\begin{array}{c}5 \\
(71)\end{array}$ & $\begin{array}{c}1.37 \\
(0.69-1.51)\end{array}$ & $\begin{array}{c}8 \\
(67)\end{array}$ & $\begin{array}{c}2.10 \\
(0.41-6.31)\end{array}$ & $\begin{array}{c}3 \\
(60)\end{array}$ & $\begin{array}{c}0.38 \\
(0.29-1.88)\end{array}$ & $\begin{array}{c}2 \\
(40)\end{array}$ & $\begin{array}{c}16.42 \\
(8.67-24.17)\end{array}$ & 0.822 & 0.727 \\
\hline Streptococcus & $\begin{array}{c}7 \\
(100)\end{array}$ & $\begin{array}{c}2.00 \\
(0.54-8.79)\end{array}$ & $\begin{array}{c}11 \\
(92)\end{array}$ & $\begin{array}{c}1.36 \\
(0.46-2.79)\end{array}$ & $\begin{array}{c}5 \\
(100)\end{array}$ & $\begin{array}{c}1.67 \\
(1.41-2.54)\end{array}$ & $\begin{array}{c}5 \\
(100)\end{array}$ & $\begin{array}{c}0.99 \\
(0.19-1.17)\end{array}$ & 1.000 & 0.395 \\
\hline Erysipelatoclostridium & $\begin{array}{c}5 \\
(71)\end{array}$ & $\begin{array}{c}8.39 \\
(1.74-8.78)\end{array}$ & $\begin{array}{c}4 \\
(33)\end{array}$ & $\begin{array}{c}0.25 \\
(0.18-1.99)\end{array}$ & $\begin{array}{c}2 \\
(40)\end{array}$ & $\begin{array}{c}0.38 \\
(0.34-0.43)\end{array}$ & $\begin{array}{c}1 \\
(20)\end{array}$ & 0.25 & 0.333 & 0.012 \\
\hline Veillonella & $\begin{array}{c}5 \\
(71)\end{array}$ & $\begin{array}{c}0.70 \\
(0.39-3.78)\end{array}$ & $\begin{array}{c}9 \\
(75)\end{array}$ & $\begin{array}{c}0.49 \\
(0.34-0.76)\end{array}$ & $\begin{array}{c}3 \\
(60)\end{array}$ & $\begin{array}{c}1.59 \\
(0.97-12.42)\end{array}$ & $\begin{array}{c}5 \\
(100)\end{array}$ & $\begin{array}{c}0.89 \\
(0.20-1.19)\end{array}$ & 0.579 & 0.665 \\
\hline \multicolumn{11}{|l|}{ Proteobacteria } \\
\hline Escherichia_Shigella & $\begin{array}{c}5 \\
(71)\end{array}$ & $\begin{array}{c}9.56 \\
(0.66-14.73)\end{array}$ & $\begin{array}{c}8 \\
(67)\end{array}$ & $\begin{array}{c}1.40 \\
(0.47-4.19)\end{array}$ & $\begin{array}{c}3 \\
(60)\end{array}$ & $\begin{array}{c}2.42 \\
(1.28-40.69)\end{array}$ & $\begin{array}{c}5 \\
(100)\end{array}$ & $\begin{array}{c}6.56 \\
(0.52-51.11)\end{array}$ & 0.552 & 0.871 \\
\hline Klebsiella & $\begin{array}{c}1 \\
(14)\end{array}$ & 6.32 & $\begin{array}{c}4 \\
(33)\end{array}$ & $\begin{array}{c}6.15 \\
(4.26-6.89)\end{array}$ & $\begin{array}{c}1 \\
(20)\end{array}$ & $\begin{array}{c}2.81 \\
(2.27-3.34)\end{array}$ & $\begin{array}{c}3 \\
(60)\end{array}$ & $\begin{array}{c}0.37 \\
(0.33-6.93)\end{array}$ & 0.510 & 0.884 \\
\hline Unclassified_Enterobacteriaceae & $\begin{array}{c}3 \\
(43)\end{array}$ & $\begin{array}{c}0.95 \\
(0.85-27.89)\end{array}$ & $\begin{array}{c}5 \\
(42)\end{array}$ & $\begin{array}{c}1.21 \\
(0.38-4.62)\end{array}$ & $\begin{array}{c}4 \\
(80)\end{array}$ & $\begin{array}{c}4.82 \\
(1.27-19.49)\end{array}$ & $\begin{array}{c}3 \\
(60)\end{array}$ & $\begin{array}{c}0.55 \\
(0.35-0.76)\end{array}$ & 0.579 & 0.488 \\
\hline
\end{tabular}

CMPA, Cow's milk protein allergy. Frequency is expressed as the number (\%) of samples in which the genus was detected. The relative abundance is expressed as the median (IQR). * Freeman-Halton extension of the Fisher exact probability test for a $2 \times 4$ contingency table was used to evaluate differences in detection frequencies of the analyzed bacterial genera between groups. ${ }^{* *}$ Kruskal-Wallis tests were used to evaluate differences in the relative abundances of each genus between groups. 


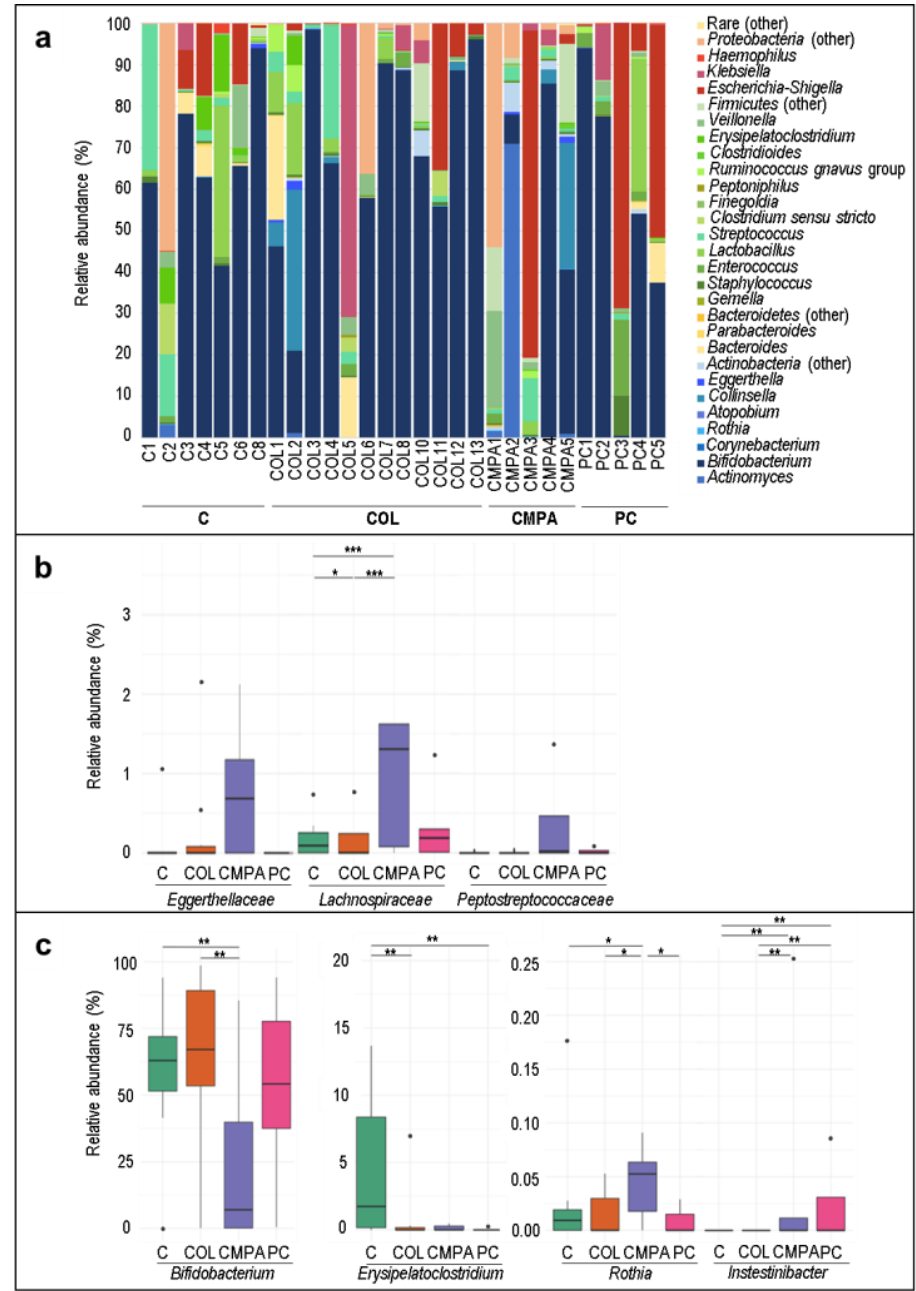

Figure 1. Bacterial composition of infant fecal samples: (a) Relative abundance of the major bacterial genera detected in $\geq 15 \%$ of the fecal samples; (b) Relative abundances of the significantly different bacterial families and (c) Relative abundances of the significantly different bacterial genera resulting from LEfSe analysis of the fecal samples $(N=29)$. Statistical differences between the study groups are indicated with an asterisk $\left({ }^{*}, p<0.10 ;{ }^{* *}, p<0.05 ;{ }^{* * *}, p<0.01\right.$; Dunn test). C, Control group $(n=7)$; COL, Colic group $(n=12)$; CMPA, Cow's milk protein allergy group $(n=5)$; PC, Proctocolitis group . In these boxplots, the central rectangle represents the interquartile range (IQR), the line and the cross inside the rectangle show the median and the mean, respectively; the whiskers indicate the maximum and minimum values, and the black dots outside the rectangles are suspected outliers $(>1.5 \times \mathrm{IQR})$.

The median number of the observed species was significantly higher in fecal samples of the CMPA group when compared with samples of the control group (Figure $2 \mathrm{a} ; p<0.001$ ). Differences were not observed in the bacterial diversity calculated as the Shannon Index (Figure 2b). The analysis of the beta diversity in samples of the three disease groups together did not reveal distinct microbial profiles when compared to samples of the control group (Figure 2c,d). 


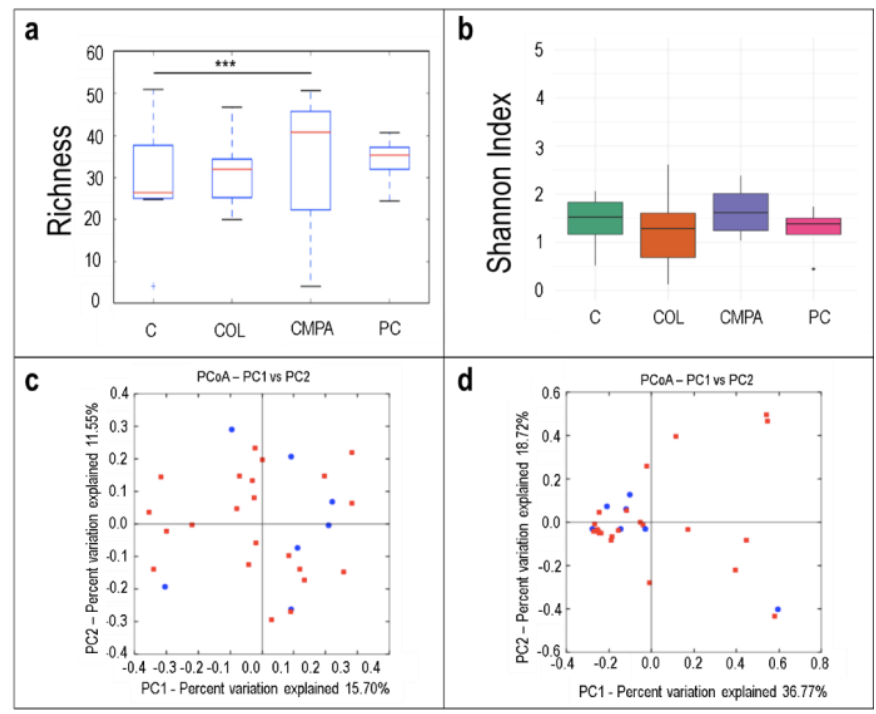

Figure 2. Alpha diversity in the fecal samples $(N=29)$ in the different study groups expressed by: (a) the number of the observed species (species richness) and (b) the Shannon Index. Beta diversity analysis of the study groups measured as: (c) the presence/absence (Binnary Jaccard method; $p=0.917$ ) and (d) the relative abundance (Bray Curtis method; $p=0.839$ ) of the different species quantified in all disease groups (red) and controls (blue). C, Control group $(n=7)$; COL, Colic group $(n=12)$; CMPA, Cow's milk protein allergy group $(n=5)$; PC, Proctocolitis group $(n=5)$.

\subsection{Metataxonomic Profiling of the Milk Samples}

The most abundant bacterial genera in milk samples were Streptococcus and Staphylococcus, followed by genera of the family Enterobacteriaceae (Figure 3a and Table 3). Acinetobacter, Corynebacterium, Lactobacillus, and Gemella were also present but at lower concentration. Similar to what has been described above for the fecal samples, the most abundant genera were detected in all the study groups and their detection frequency and concentrations did not differ significantly between the study groups (Table 3). However, in paired comparisons between groups, the relative abundance of the family Eggerthellaceae was significantly higher in CMPA than in the control and colic groups (Figure 3b). In addition, Prolixibacteraceae was higher in the proctocolitis group than in the CMPA group (Figure 3b).

Regarding the alpha diversity of milk samples, no differences were obtained when comparing the bacterial richness and the Shannon index values due to the high interindividual variability of the samples (Figure 4a,b, respectively). The beta diversity analysis did not reveal characteristic microbial profiles for the control group or for the three disease groups together (Figure 4c,d). 
Table 3. Frequency and relative abundance of operational taxonomic units at genus level in milk samples from participants $(N=26)$ in each group of study: control, colic, cow's milk protein allergy (CMPA), and proctocolitis.

\begin{tabular}{|c|c|c|c|c|c|c|c|c|c|c|}
\hline \multirow[b]{2}{*}{$\begin{array}{l}\text { Phylum } \\
\text { Genus }\end{array}$} & \multicolumn{2}{|c|}{$\begin{array}{c}\text { Control Group } \\
(n=8)\end{array}$} & \multicolumn{2}{|c|}{$\begin{array}{l}\text { Colic Group } \\
\quad(n=11)\end{array}$} & \multicolumn{2}{|c|}{$\begin{array}{c}\text { CMPA Group } \\
(n=3)\end{array}$} & \multicolumn{2}{|c|}{$\begin{array}{c}\text { Proctocolitis Group } \\
(n=4)\end{array}$} & \multirow[b]{2}{*}{$p^{*}$} & \multirow[b]{2}{*}{$p^{* *}$} \\
\hline & $\begin{array}{c}n \\
(\%)\end{array}$ & $\begin{array}{l}\text { Median } \\
\text { (IQR) }\end{array}$ & $\begin{array}{c}n \\
(\%)\end{array}$ & $\begin{array}{l}\text { Median } \\
\text { (IQR) }\end{array}$ & $\begin{array}{c}n \\
(\%)\end{array}$ & $\begin{array}{l}\text { Median } \\
\text { (IQR) }\end{array}$ & $\begin{array}{c}n \\
(\%)\end{array}$ & $\begin{array}{l}\text { Median } \\
\text { (IQR) }\end{array}$ & & \\
\hline \multicolumn{11}{|l|}{ Actinobacteria } \\
\hline Corynebacterium & $\begin{array}{c}7 \\
(88)\end{array}$ & $\begin{array}{c}0.88 \\
(0.31-1.76)\end{array}$ & $\begin{array}{c}10 \\
(91)\end{array}$ & $\begin{array}{c}0.27 \\
(0.19-0.86)\end{array}$ & $\begin{array}{c}2 \\
(67)\end{array}$ & $\begin{array}{c}1.42 \\
(0.78-2.05)\end{array}$ & $\begin{array}{c}2 \\
(50)\end{array}$ & $\begin{array}{c}0.51 \\
(0.38-0.64)\end{array}$ & 0.238 & 0.735 \\
\hline Kocuria & $\begin{array}{c}2 \\
(25)\end{array}$ & $\begin{array}{c}1.18 \\
(1.08-1.29)\end{array}$ & $\begin{array}{c}4 \\
(36)\end{array}$ & $\begin{array}{c}0.55 \\
(0.22-6.97)\end{array}$ & $\begin{array}{c}2 \\
(67)\end{array}$ & $\begin{array}{c}0.98 \\
(0.77-1.18)\end{array}$ & $\begin{array}{c}2 \\
(50)\end{array}$ & $\begin{array}{c}1.38 \\
(0.75-2.01)\end{array}$ & 0.702 & 0.865 \\
\hline \multicolumn{11}{|l|}{ Firmicutes } \\
\hline Bacillus & $\begin{array}{c}4 \\
(57)\end{array}$ & $\begin{array}{c}2.78 \\
(0.54-5.52)\end{array}$ & $\begin{array}{c}8 \\
(67)\end{array}$ & $\begin{array}{c}0.45 \\
(0.22-4.29)\end{array}$ & $\begin{array}{c}0 \\
(0)\end{array}$ & - & $\begin{array}{c}2 \\
(50)\end{array}$ & $\begin{array}{c}3.60 \\
(2.09-5.11)\end{array}$ & 0.178 & 0.555 \\
\hline Gemella & $\begin{array}{c}5 \\
(63)\end{array}$ & $\begin{array}{c}0.52 \\
(0.31-0.83)\end{array}$ & $\begin{array}{c}6 \\
(55)\end{array}$ & $\begin{array}{c}1.89 \\
(0.66-4.71)\end{array}$ & $\begin{array}{c}1 \\
(33)\end{array}$ & 0.11 & $\begin{array}{c}2 \\
(50)\end{array}$ & $\begin{array}{c}1.75 \\
(1.43-2.07))\end{array}$ & 0.940 & 0.150 \\
\hline Lactobacillus & $\begin{array}{c}5 \\
(63)\end{array}$ & $\begin{array}{c}0.47 \\
(0.30-1.93)\end{array}$ & $\begin{array}{c}10 \\
(91)\end{array}$ & $\begin{array}{c}0.98 \\
(0.39-1.59)\end{array}$ & $\begin{array}{c}2 \\
(67)\end{array}$ & $\begin{array}{c}0.86 \\
(0.67-1.04)\end{array}$ & $\begin{array}{c}3 \\
(75)\end{array}$ & $\begin{array}{c}1.19 \\
(0.74-2.49)\end{array}$ & 0.174 & 0.990 \\
\hline Staphylococcus & $\begin{array}{c}8 \\
(100)\end{array}$ & $\begin{array}{c}9.63^{\circ} \\
(1.88-51.35)\end{array}$ & $\begin{array}{c}11 \\
(100)\end{array}$ & $\begin{array}{c}1.93 \\
(1.06-8.61)\end{array}$ & $\begin{array}{c}2 \\
(67)\end{array}$ & $\begin{array}{c}6.26 \\
(5.19-7.33)\end{array}$ & $\begin{array}{c}4 \\
(100)\end{array}$ & $\begin{array}{c}9.44 \\
(3.24-17.64)\end{array}$ & 0.115 & 0.652 \\
\hline Streptococcus & $\begin{array}{c}8 \\
(100) \\
\end{array}$ & $\begin{array}{c}17.18 \\
(5.08-48.80) \\
\end{array}$ & $\begin{array}{c}11 \\
(100) \\
\end{array}$ & $\begin{array}{c}23.70 \\
(12.72-36.92) \\
\end{array}$ & $\begin{array}{c}2 \\
(67) \\
\end{array}$ & $\begin{array}{c}20.48 \\
(16.30-24.66) \\
\end{array}$ & $\begin{array}{c}4 \\
(100) \\
\end{array}$ & $\begin{array}{c}35.09 \\
(12.29-65.44) \\
\end{array}$ & 0.115 & 0.905 \\
\hline \multicolumn{11}{|l|}{ Proteobacteria } \\
\hline Acinetobacter & $\begin{array}{c}7 \\
(88)\end{array}$ & $\begin{array}{c}2.95 \\
(0.59-5.05)\end{array}$ & $\begin{array}{c}9 \\
(82)\end{array}$ & $\begin{array}{c}1.32 \\
(0.36-1.52)\end{array}$ & $\begin{array}{c}3 \\
(100)\end{array}$ & $\begin{array}{c}0.43 \\
(0.28-0.56)\end{array}$ & $\begin{array}{c}4 \\
(100)\end{array}$ & $\begin{array}{c}2.28 \\
(0.22-4.53)\end{array}$ & 1.000 & 0.367 \\
\hline Pseudomonas & $\begin{array}{c}4 \\
(50)\end{array}$ & $\begin{array}{c}0.37 \\
(0.28-17.02)\end{array}$ & $\begin{array}{c}6 \\
(55)\end{array}$ & $\begin{array}{c}0.28 \\
(0.18-0.39)\end{array}$ & $\begin{array}{c}2 \\
(67)\end{array}$ & $\begin{array}{c}0.37 \\
(0.34-0.40)\end{array}$ & $\begin{array}{c}3 \\
(75)\end{array}$ & $\begin{array}{c}0.96 \\
(0.83-1.11)\end{array}$ & 0.886 & 0.303 \\
\hline Unclassified_Enterobacteriaceae & $\begin{array}{c}8 \\
(100)\end{array}$ & $\begin{array}{c}9.64 \\
(4.52-19.69)\end{array}$ & $\begin{array}{c}10 \\
(91)\end{array}$ & $\begin{array}{c}3.89 \\
(2.82-13.42)\end{array}$ & $\begin{array}{c}3 \\
(100)\end{array}$ & $\begin{array}{c}62.68 \\
(49.53-78.66)\end{array}$ & $\begin{array}{c}3 \\
(75)\end{array}$ & $\begin{array}{c}1.39 \\
(1.36-31.67)\end{array}$ & 0.560 & 0.117 \\
\hline
\end{tabular}

CMPA, Cow's milk protein allergy. Frequency is expressed as the number (\%) of samples in which the genus was detected. The relative abundance is expressed as the median (IQR). * Freeman-Halton extension of the Fisher exact probability test for a $2 \times 4$ contingency table was used to evaluate differences in detection frequencies of the analyzed bacterial genera between groups. ${ }^{* *}$ Kruskal-Wallis tests were used to evaluate differences in the relative abundances of each genus between groups. 


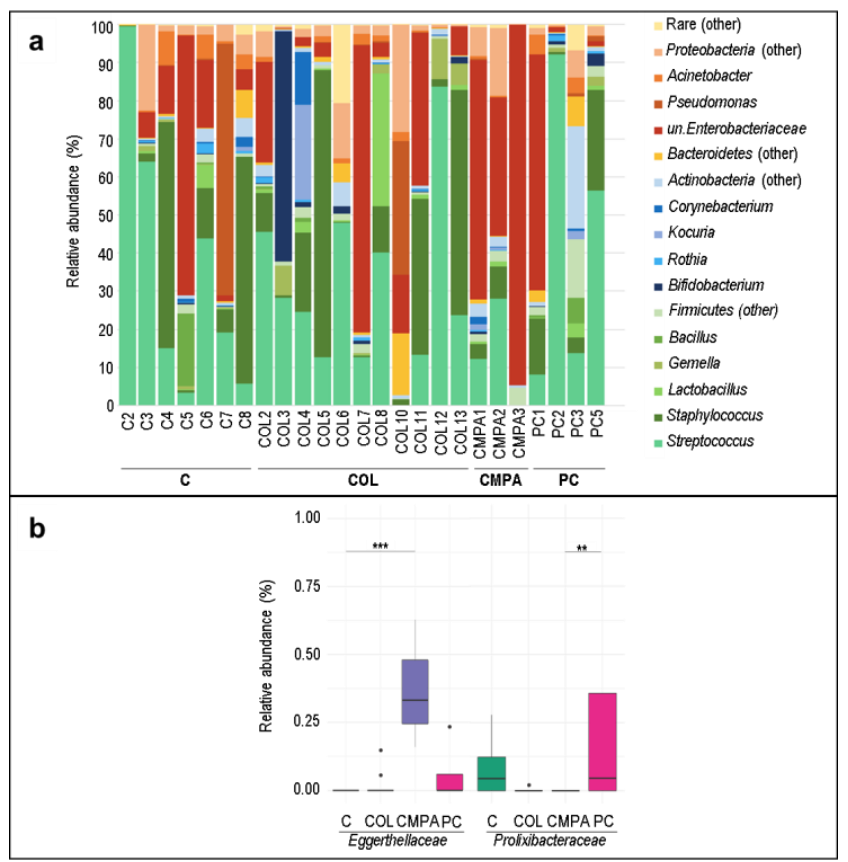

Figure 3. Bacterial composition of milk samples: (a) Relative abundance of the major bacterial genera detected in $\geq 15 \%$ of the milk samples; (b) Relative abundances of the significantly different bacterial families resulting from LEfSe analysis of the milk samples $(N=25)$. Statistical differences between the study groups are indicated with an asterisk ${ }^{* *}, p<0.05 ;{ }^{* * *}, p<0.01$; Dunn test). C, Control group $(n=7)$; COL, Colic group $(n=11)$; CMPA, Cow's milk protein allergy group $(n=3)$; PC, Proctocolitis group $(n=4)$. In these boxplots, the central rectangle represents the interquartile range (IQR), the line and the cross inside the rectangle show the median and the mean, respectively; the whiskers indicate the maximum and minimum values, and the black dots outside the rectangles are suspected outliers $(>1.5 \times \mathrm{IQR})$.

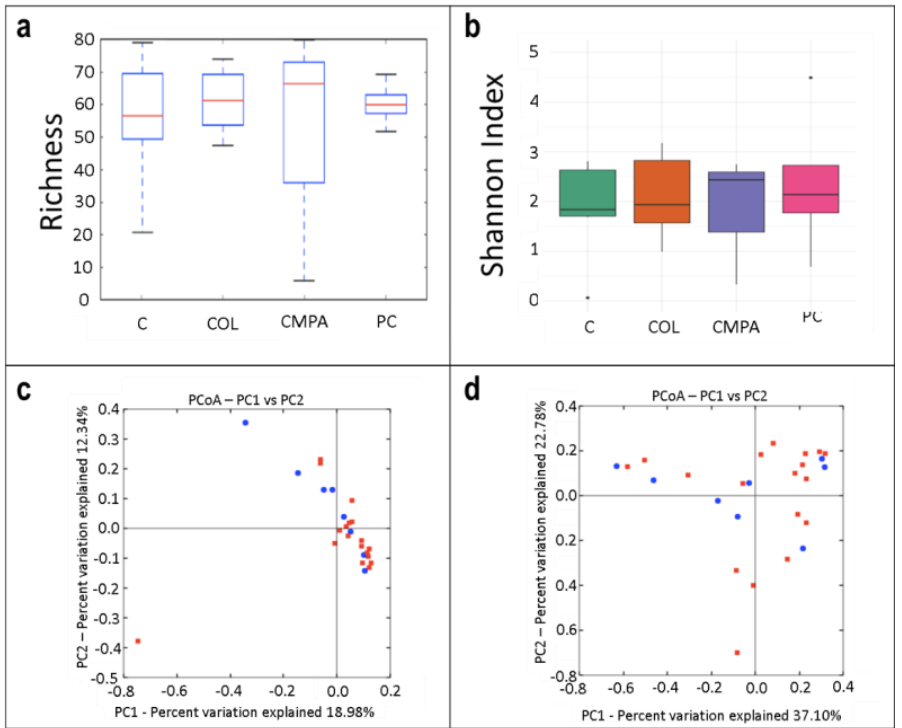

Figure 4. Alpha diversity in the milk samples $(N=25)$ in the different study groups expressed by: (a) the number of the observed species (species richness) and (b) the Shannon Index. Beta diversity analysis of the study groups measured as: (c) the presence/absence (Binnary Jaccard method; $p=0.794$ ) and (d) the relative abundance (Bray Curtis method; $p=0.912$ ) of the different species quantified in all disease groups (red) and controls (blue). C, Control group $(n=7)$; COL, Colic group $(n=11)$; CMPA, Cow's milk protein allergy group $(n=3)$; PC, Proctocolitis group $(n=4)$. 


\subsection{Concentration and Frequency of Detection of Immune Factors in the Infant Fecal Samples}

All the immune compounds were detected at least in one of the infant fecal samples analyzed (Table 4). IL12, IL2, IL17 and IL5 were present in all the fecal samples, and IL1 $\beta$, IL6, IL8, IL10, GCSF, GMCSF, MIP1 $\beta$ and TNF $\alpha$ were detected in more than $50 \%$ of them. GCSF was found at a lower frequency in the CMPA and proctocolitis groups $(60 \%$ and $75 \%$, respectively) than in the control and colic groups $(100 \%)(p=0.036)$ (Table 4$)$.

There was a large interindividual variability in the concentration of the immunological compounds of infant fecal samples. The median (IQR) value of IL10 content in fecal samples from the proctocolitis, CMPA, and control groups were 8.00 (5.80-11.50) ng/L, 937.42 (472.71-1105.06) ng/L, and 34.60 (27.10-42.209) ng/L, respectively, but the differences did not reach the statistical significance (Table 4). A similar observation could be made about the median (IQR) value of IL7 concentration in feces of infants with colic and controls that were 8.60 (8.60-35.90) ng/L and 86.30 (74.00-100.37) ng/L, respectively (Table 4).

\subsection{Concentration and Frequency of Detection of Immune Factors in Milk Samples}

Globally, all the immune compounds were also present at least in one of the milk samples analyzed (Table 5). MIP1 $\beta$ was the only factor present in all samples, and IL1 $\beta$, IL6, IL8, IL12, IL13 and MCP1 were found in more than the $50 \%$ of the samples. When all groups were compared, statistically significant differences were obtained in the concentration and/or frequency of all the compounds related to acquired immunity (IL2, IL4, IL10, IL13, IL17) and GCSF (Table 5). IL2 was only detected in milk samples of the CMPA group, and IL10 and IL17 concentrations were also higher in this group (median (IQR) concentrations of 24.00 (13.51-29.46) ng/L and 20.19 (14.15-26.23) ng/L, respectively). On the other hand, IL13 concentration was lower in mother's milk of the infants with colics when compared with the rest of the groups (Table 5). 
Table 4. Frequency and concentration of immune factors in fecal samples $(N=28)$ from participants in each group of study: control, colic, cow's milk protein allergy (CMPA), and proctocolitis.

\begin{tabular}{|c|c|c|c|c|c|c|c|c|c|c|}
\hline \multirow[b]{2}{*}{ Immune factor } & \multicolumn{2}{|c|}{$\begin{array}{c}\text { Control Group } \\
(n=7)\end{array}$} & \multicolumn{2}{|c|}{$\begin{array}{l}\text { Colic Group } \\
\quad(n=12)\end{array}$} & \multicolumn{2}{|c|}{$\begin{array}{c}\text { CMPA Group } \\
(n=5)\end{array}$} & \multicolumn{2}{|c|}{$\begin{array}{c}\text { Proctocolitis Group } \\
(n=5)\end{array}$} & \multirow[b]{2}{*}{$p^{*}$} & \multirow[b]{2}{*}{$p^{* *}$} \\
\hline & $\begin{array}{c}n \\
(\%)\end{array}$ & $\begin{array}{l}\text { Median } \\
\text { (IQR) }\end{array}$ & $\begin{array}{c}n \\
(\%)\end{array}$ & $\begin{array}{l}\text { Median } \\
\text { (IQR) }\end{array}$ & $\begin{array}{c}n \\
(\%)\end{array}$ & $\begin{array}{l}\text { Median } \\
\text { (IQR) }\end{array}$ & $\begin{array}{c}n \\
(\%)\end{array}$ & $\begin{array}{l}\text { Median } \\
\text { (IQR) }\end{array}$ & & \\
\hline \multicolumn{11}{|l|}{ Innate immunity } \\
\hline $\operatorname{IL} 1 \beta(\mathrm{ng} / \mathrm{L})$ & $\begin{array}{c}6 \\
(86)\end{array}$ & $\begin{array}{c}533.20 \\
(33.88-1528.44)\end{array}$ & $\begin{array}{c}11 \\
(92)\end{array}$ & $\begin{array}{c}33.29 \\
(13.25-112.96)\end{array}$ & $\begin{array}{c}3 \\
(60)\end{array}$ & $\begin{array}{c}12.90 \\
(9.30-102.99)\end{array}$ & $\begin{array}{c}4 \\
(100)\end{array}$ & $\begin{array}{c}23.80 \\
(13.85-43.85)\end{array}$ & 0.300 & 0.593 \\
\hline IL6 (ng/L) & $\begin{array}{c}6 \\
(86)\end{array}$ & $\begin{array}{c}10.75 \\
(6.68-13.93)\end{array}$ & $\begin{array}{c}12 \\
(100)\end{array}$ & $\begin{array}{c}9.32 \\
(5.50-11.08)\end{array}$ & $\begin{array}{c}5 \\
(100)\end{array}$ & $\begin{array}{c}5.50 \\
(1.00-32.30)\end{array}$ & $\begin{array}{c}4 \\
(100)\end{array}$ & $\begin{array}{c}5.50 \\
(4.38-8.13)\end{array}$ & 0.571 & 0.796 \\
\hline IL12(p70) (ng/L) & $\begin{array}{c}7 \\
(100)\end{array}$ & $\begin{array}{c}60.30 \\
(48.24-64.85)\end{array}$ & $\begin{array}{c}12 \\
(100)\end{array}$ & $\begin{array}{c}37.35 \\
(27.55-48.93)\end{array}$ & $\begin{array}{c}5 \\
(100)\end{array}$ & $\begin{array}{c}32.70 \\
(14.20-74.00)\end{array}$ & $\begin{array}{c}4 \\
(100)\end{array}$ & $\begin{array}{c}46.45 \\
(22.35-69.40)\end{array}$ & 1.000 & 0.492 \\
\hline $\operatorname{IFN} \gamma(\mathrm{ng} / \mathrm{L})$ & $\begin{array}{c}2 \\
(29)\end{array}$ & $\begin{array}{c}66.60 \\
(50.50-82.70)\end{array}$ & $\begin{array}{c}0 \\
(0)\end{array}$ & & $\begin{array}{c}1 \\
(20)\end{array}$ & 381.70 & $\begin{array}{c}0 \\
(0)\end{array}$ & & 0.150 & 0.221 \\
\hline $\mathrm{TNF} \alpha(\mathrm{ng} / \mathrm{L})$ & $\begin{array}{c}6 \\
(86)\end{array}$ & $\begin{array}{c}48.80 \\
(36.28-89.71)\end{array}$ & $\begin{array}{c}8 \\
(67)\end{array}$ & $\begin{array}{c}38.85 \\
(19.01-81.20)\end{array}$ & $\begin{array}{c}1 \\
(20)\end{array}$ & 48.80 & $\begin{array}{c}3 \\
(75)\end{array}$ & $\begin{array}{c}48.80 \\
(48.80-81.55)\end{array}$ & 0.152 & 0.774 \\
\hline \multicolumn{11}{|l|}{ Acquired immunity } \\
\hline IL2 (ng/L) & $\begin{array}{c}7 \\
(100)\end{array}$ & $\begin{array}{c}54.80 \\
(33.20-62.36)\end{array}$ & $\begin{array}{c}12 \\
(100)\end{array}$ & $\begin{array}{c}36.80 \\
(20.41-41.30)\end{array}$ & $\begin{array}{c}5 \\
(100)\end{array}$ & $\begin{array}{c}51.20 \\
(44.00-51.20)\end{array}$ & $\begin{array}{c}4 \\
(100)\end{array}$ & $\begin{array}{c}58.40 \\
(58.40-60.20)\end{array}$ & 1.000 & 0.104 \\
\hline IL4 (ng/L) & $\begin{array}{c}1 \\
(14)\end{array}$ & 9.00 & $\begin{array}{c}0 \\
(0)\end{array}$ & & $\begin{array}{c}0 \\
(0)\end{array}$ & & $\begin{array}{c}0 \\
(0)\end{array}$ & & 0.571 & 0.392 \\
\hline IL10 (ng/L) & $5(71)$ & $\begin{array}{c}34.60 \\
(27.10-42.20)\end{array}$ & $\begin{array}{c}10 \\
(83)\end{array}$ & $\begin{array}{c}37.15 \\
(7.72-89.73)\end{array}$ & $\begin{array}{c}3 \\
(60)\end{array}$ & $\begin{array}{c}937.42 \\
(472.71-1105.06)\end{array}$ & $\begin{array}{c}3 \\
(75)\end{array}$ & $\begin{array}{c}8.00 \\
(5.80-11.50)\end{array}$ & 0.811 & 0.256 \\
\hline IL13 (ng/L) & $4(57)$ & $\begin{array}{c}11.68 \\
(5.90-18.63)\end{array}$ & $\begin{array}{c}4 \\
(33)\end{array}$ & $\begin{array}{c}5.10 \\
(3.23-8.58)\end{array}$ & $\begin{array}{c}0 \\
(0)\end{array}$ & & $\begin{array}{c}2 \\
(50)\end{array}$ & $\begin{array}{c}15.25 \\
(9.33-21.18)\end{array}$ & 0.200 & 0.621 \\
\hline IL17 (ng/L) & $7(100)$ & $\begin{array}{c}66.20 \\
(46.15-120.01)\end{array}$ & $\begin{array}{c}12 \\
(100)\end{array}$ & $\begin{array}{c}61.28 \\
(36.10-72.58)\end{array}$ & $\begin{array}{c}5 \\
(100)\end{array}$ & $\begin{array}{c}51.10 \\
(51.10-96.80)\end{array}$ & $\begin{array}{c}4 \\
(100)\end{array}$ & $\begin{array}{c}26.20 \\
(15.10-48.73)\end{array}$ & 1.000 & 0.514 \\
\hline \multicolumn{11}{|l|}{ Chemokines } \\
\hline IL8 (ng/L) & $\begin{array}{c}5 \\
(71)\end{array}$ & $\begin{array}{c}14.30 \\
(9.09-27.00)\end{array}$ & $\begin{array}{c}7 \\
(58)\end{array}$ & $\begin{array}{c}4.80 \\
(3.00-7.95)\end{array}$ & $\begin{array}{c}1 \\
(20)\end{array}$ & 4.80 & $\begin{array}{c}3 \\
(75)\end{array}$ & $\begin{array}{c}11.10 \\
(7.95-17.45)\end{array}$ & 0.351 & 0.407 \\
\hline MCP1 (ng/L) & $\begin{array}{c}3 \\
(43)\end{array}$ & $\begin{array}{c}32.50 \\
(28.59-43.15)\end{array}$ & $\begin{array}{c}2 \\
(17)\end{array}$ & $\begin{array}{c}4.54 \\
(2.64-6.45)\end{array}$ & $\begin{array}{c}0 \\
(0)\end{array}$ & & $\begin{array}{c}1 \\
(25)\end{array}$ & 7.00 & 0.377 & 0.145 \\
\hline MIP1 $\beta(n g / L)$ & $\begin{array}{c}6 \\
(86)\end{array}$ & $\begin{array}{c}22.30 \\
(17.58-29.43)\end{array}$ & $\begin{array}{c}8 \\
(67)\end{array}$ & $\begin{array}{c}39.19 \\
(16.54-76.90)\end{array}$ & $\begin{array}{c}1 \\
(20)\end{array}$ & 381.60 & $\begin{array}{c}2 \\
(50)\end{array}$ & $\begin{array}{c}108.70 \\
(100.55-116.85)\end{array}$ & 0.134 & 0.279 \\
\hline
\end{tabular}


Table 4. Cont

\begin{tabular}{|c|c|c|c|c|c|c|c|c|c|c|}
\hline \multirow[b]{2}{*}{ Immune factor } & \multicolumn{2}{|c|}{$\begin{array}{c}\text { Control Group } \\
(n=7)\end{array}$} & \multicolumn{2}{|c|}{$\begin{array}{c}\text { Colic Group } \\
(n=12)\end{array}$} & \multicolumn{2}{|c|}{$\begin{array}{c}\text { CMPA Group } \\
(n=5)\end{array}$} & \multicolumn{2}{|c|}{$\begin{array}{c}\text { Proctocolitis Group } \\
(n=5)\end{array}$} & \multirow[b]{2}{*}{$p^{*}$} & \multirow[b]{2}{*}{$p^{* *}$} \\
\hline & $\begin{array}{c}n \\
(\%)\end{array}$ & $\begin{array}{l}\text { Median } \\
\text { (IQR) }\end{array}$ & $\begin{array}{c}n \\
(\%)\end{array}$ & $\begin{array}{l}\text { Median } \\
\text { (IQR) }\end{array}$ & $\begin{array}{c}n \\
(\%)\end{array}$ & $\begin{array}{l}\text { Median } \\
\text { (IQR) }\end{array}$ & $\begin{array}{c}n \\
(\%)\end{array}$ & $\begin{array}{l}\text { Median } \\
\text { (IQR) }\end{array}$ & & \\
\hline \multicolumn{11}{|l|}{$\begin{array}{l}\text { Hematopoyetic } \\
\text { factors }\end{array}$} \\
\hline IL5 (ng/L) & $\begin{array}{c}7 \\
(100)\end{array}$ & $\begin{array}{c}91.90 \\
(86.33-166.85)\end{array}$ & $\begin{array}{c}12 \\
(100)\end{array}$ & $\begin{array}{c}59.95 \\
(32.54-110.85)\end{array}$ & $\begin{array}{c}5 \\
(100)\end{array}$ & $\begin{array}{c}99.90 \\
(84.00-99.90)\end{array}$ & $\begin{array}{c}4 \\
(100)\end{array}$ & $\begin{array}{c}151.15 \\
(131.40-164.88)\end{array}$ & 1.000 & 0.301 \\
\hline IL7 (ng/L) & $\begin{array}{c}5 \\
(71)\end{array}$ & $\begin{array}{c}86.30 \\
(74.00-100.37)\end{array}$ & $\begin{array}{c}5 \\
(42)\end{array}$ & $\begin{array}{c}8.60 \\
(8.60-35.90)\end{array}$ & $\begin{array}{c}1 \\
(20)\end{array}$ & 35.86 & $\begin{array}{c}1 \\
(25)\end{array}$ & 98.40 & 0.352 & 0.152 \\
\hline GCSF $(\mu \mathrm{g} / \mathrm{L})$ & $\begin{array}{c}7 \\
(100)\end{array}$ & $\begin{array}{c}400.50 \\
(109.60-575.50)\end{array}$ & $\begin{array}{c}12 \\
(100)\end{array}$ & $\begin{array}{c}295.15 \\
(119.29-796.05)\end{array}$ & $\begin{array}{c}3 \\
(60)\end{array}$ & $\begin{array}{c}445.90 \\
(378.00-869.51)\end{array}$ & $\begin{array}{c}3 \\
(75)\end{array}$ & $\begin{array}{c}87.60 \\
(44.60-396.50)\end{array}$ & 0.036 & 0.564 \\
\hline GMCSF ( $\mu \mathrm{g} / \mathrm{L})$ & $\begin{array}{c}6 \\
(86)\end{array}$ & $\begin{array}{c}12.95 \\
(8.55-18.99)\end{array}$ & $\begin{array}{c}8 \\
(67)\end{array}$ & $\begin{array}{c}12.20 \\
(3.63-18.60)\end{array}$ & $\begin{array}{c}3 \\
(60)\end{array}$ & $\begin{array}{c}45.30 \\
(27.30-54.13)\end{array}$ & $\begin{array}{c}3 \\
(75)\end{array}$ & $\begin{array}{c}15.10 \\
(12.95-17.95)\end{array}$ & 0.824 & 0.404 \\
\hline
\end{tabular}

CMPA, Cow's milk protein allergy; GCSF, granulocyte colony-stimulating factor; GMCSF, granulocyte-macrophage colony-stimulating factor; IFN $\gamma$, interferon- $\gamma$; IL, interleukin; MCP1, macrophage-monocyte chemoattractant protein-1; MIP1 $\beta$, macrophage inflammatory protein- $1 \beta$; TNF $\alpha$, tumor necrosis factor- $\alpha$. $n$ (\%), number (percentage) of samples in which the immunological compound was detected. Concentrations are expressed as median (IQR). * Freeman-Halton extension of the Fisher exact probability test for a $2 \times 4$ contingency table was used to evaluate differences in expression frequencies of the analyzed parameters between groups. ${ }^{* *}$ Kruskal-Wallis tests were used to evaluate differences in the concentration of the different immune factors between groups. 
Table 5. Frequency and concentration of immune factors in milk samples $(N=25)$ from participants in each group of study: control, colic, cow's milk protein allergy (CMPA), and proctocolitis.

\begin{tabular}{|c|c|c|c|c|c|c|c|c|c|c|}
\hline \multirow[b]{2}{*}{ Immune factor } & \multicolumn{2}{|c|}{$\begin{array}{l}\text { Control Group } \\
\quad(n=7)\end{array}$} & \multicolumn{2}{|c|}{$\begin{array}{l}\text { Colic Group } \\
(n=12)\end{array}$} & \multicolumn{2}{|c|}{$\begin{array}{c}\text { CMPA Group } \\
(n=5)\end{array}$} & \multicolumn{2}{|c|}{$\begin{array}{l}\text { Proctocolitis Group } \\
\quad(n=5)\end{array}$} & \multirow[b]{2}{*}{$p^{*}$} & \multirow[b]{2}{*}{$p^{* *}$} \\
\hline & $\begin{array}{c}n \\
(\%)\end{array}$ & $\begin{array}{l}\text { Median } \\
\text { (IQR) }\end{array}$ & $\begin{array}{c}n \\
(\%)\end{array}$ & $\begin{array}{l}\text { Median } \\
\text { (IQR) }\end{array}$ & $\begin{array}{c}n \\
(\%)\end{array}$ & $\begin{array}{l}\text { Median } \\
\text { (IQR) }\end{array}$ & $\begin{array}{c}n \\
(\%)\end{array}$ & $\begin{array}{l}\text { Median } \\
\text { (IQR) }\end{array}$ & & \\
\hline \multicolumn{11}{|l|}{ Innate immunity } \\
\hline $\operatorname{IL} 1 \beta(n g / L)$ & $\begin{array}{c}6 \\
(86)\end{array}$ & $\begin{array}{c}0.73 \\
(0.41-1.18)\end{array}$ & $\begin{array}{c}6 \\
(55)\end{array}$ & $\begin{array}{c}0.78 \\
(0.19-9.95)\end{array}$ & $\begin{array}{c}2 \\
(67)\end{array}$ & $\begin{array}{c}0.22 \\
(0.14-0.29)\end{array}$ & $\begin{array}{c}4 \\
(100)\end{array}$ & $\begin{array}{c}3.85 \\
(2.02-8.28)\end{array}$ & 0.339 & 0.075 \\
\hline IL6 (ng/L) & $\begin{array}{c}4 \\
(57)\end{array}$ & $\begin{array}{c}5.49 \\
(3.66-9.07)\end{array}$ & $\begin{array}{c}5 \\
(45)\end{array}$ & $\begin{array}{c}2.21 \\
(2.21-8.25)\end{array}$ & $\begin{array}{c}2 \\
(67)\end{array}$ & $\begin{array}{c}8.94 \\
(5.58-12.31)\end{array}$ & $\begin{array}{c}4 \\
(100)\end{array}$ & $\begin{array}{c}2.65 \\
(1.40-4.30)\end{array}$ & 0.579 & 0.677 \\
\hline IL12(p70) (ng/L) & $\begin{array}{c}4 \\
(57)\end{array}$ & $\begin{array}{c}4.18 \\
(3.50-5.39)\end{array}$ & $\begin{array}{c}5 \\
(45)\end{array}$ & $\begin{array}{c}5.07 \\
(3.28-7.68)\end{array}$ & $\begin{array}{c}2 \\
(67)\end{array}$ & $\begin{array}{c}7.89 \\
(7.57-8.21)\end{array}$ & $\begin{array}{c}3 \\
(75)\end{array}$ & $\begin{array}{c}2.82 \\
(2.11-4.17)\end{array}$ & 0.875 & 0.711 \\
\hline $\mathrm{IFN} \gamma(\mathrm{ng} / \mathrm{L})$ & $\begin{array}{c}1 \\
(14)\end{array}$ & 18.24 & $\begin{array}{c}0 \\
(0)\end{array}$ & & $\begin{array}{c}0 \\
(0)\end{array}$ & & $\begin{array}{c}0 \\
(0)\end{array}$ & & 0.586 & - \\
\hline $\mathrm{TNF} \alpha(\mathrm{ng} / \mathrm{L})$ & $\begin{array}{c}2 \\
(29) \\
\end{array}$ & $\begin{array}{c}5.14 \\
(3.79-6.48) \\
\end{array}$ & $\begin{array}{c}4 \\
(36) \\
\end{array}$ & $\begin{array}{c}3.55 \\
(2.70-5.14) \\
\end{array}$ & $\begin{array}{c}2 \\
(67) \\
\end{array}$ & $\begin{array}{c}6.24 \\
(5.98-6.51) \\
\end{array}$ & $\begin{array}{c}2 \\
(50) \\
\end{array}$ & $\begin{array}{c}2.44 \\
(1.89-3.00) \\
\end{array}$ & 1.000 & 0.594 \\
\hline $\begin{array}{l}\text { Acquired immunity } \\
\text { IL2 (ng/L) }\end{array}$ & $\begin{array}{c}0 \\
(0)\end{array}$ & & $\begin{array}{c}0 \\
(0)\end{array}$ & & $\begin{array}{c}2 \\
(67)\end{array}$ & $\begin{array}{c}5.69 \\
(4.33-7.06)\end{array}$ & $\begin{array}{c}0 \\
(0)\end{array}$ & & 0.049 & 0.002 \\
\hline IL4 (ng/L) & $\begin{array}{c}3 \\
(43)\end{array}$ & $\begin{array}{c}0.33 \\
(0.33-0.75)\end{array}$ & $\begin{array}{c}1 \\
(9)\end{array}$ & 0.14 & $\begin{array}{c}2 \\
(67)\end{array}$ & $\begin{array}{c}0.69 \\
(0.61-0.76)\end{array}$ & $\begin{array}{c}3 \\
(75)\end{array}$ & $\begin{array}{c}0.24 \\
(0.14-0.29)\end{array}$ & 0.115 & 0.060 \\
\hline IL10 (ng/L) & $\begin{array}{c}4 \\
(57)\end{array}$ & $\begin{array}{c}2.51 \\
(2.38-4.24)\end{array}$ & $\begin{array}{c}3 \\
(27)\end{array}$ & $\begin{array}{c}2.25 \\
(2.12-10.12)\end{array}$ & $\begin{array}{c}3 \\
(100)\end{array}$ & $\begin{array}{c}24.00 \\
(13.51-29.46)\end{array}$ & $\begin{array}{c}1 \\
(25)\end{array}$ & 0.92 & 0.371 & 0.026 \\
\hline IL13 (ng/L) & $\begin{array}{c}6 \\
(86)\end{array}$ & $\begin{array}{c}1.42 \\
(1.07-2.08) \mathrm{a}\end{array}$ & $\begin{array}{c}4 \\
(36)\end{array}$ & $\begin{array}{c}0.62 \\
(0.31-0.87) b\end{array}$ & $\begin{array}{c}3 \\
(100)\end{array}$ & $\begin{array}{c}1.79 \\
(1.08-1.79) \mathrm{ac}\end{array}$ & $\begin{array}{c}4 \\
(100)\end{array}$ & $\begin{array}{c}2.21 \\
(1.45-3.09) \mathrm{ac}\end{array}$ & 0.126 & 0.003 \\
\hline IL17 (ng/L) & $\begin{array}{c}1 \\
(14) \\
\end{array}$ & 6.81 & $\begin{array}{c}0 \\
(0) \\
\end{array}$ & & $\begin{array}{c}2 \\
(67) \\
\end{array}$ & $\begin{array}{c}20.19 \\
(14.15-26.23) \\
\end{array}$ & $\begin{array}{c}0 \\
(0) \\
\end{array}$ & & 0.081 & 0.012 \\
\hline \multicolumn{11}{|l|}{ Chemokines } \\
\hline IL8 (ng/L) & $\begin{array}{c}7 \\
(100)\end{array}$ & $\begin{array}{c}73.19 \\
(25.12-129.25)\end{array}$ & $\begin{array}{c}11 \\
(100)\end{array}$ & $\begin{array}{c}39.95 \\
(24.46-45.51)\end{array}$ & $2(67)$ & $\begin{array}{c}49.39 \\
(44.76-54.01)\end{array}$ & $4(100)$ & $\begin{array}{c}142.55 \\
(113.37-177.55)\end{array}$ & 0.036 & 0.091 \\
\hline MCP1 (ng/L) & $\begin{array}{c}6 \\
(86)\end{array}$ & $\begin{array}{c}79.61 \\
(30.43-145.76)\end{array}$ & $\begin{array}{c}8 \\
(73)\end{array}$ & $\begin{array}{c}150.45 \\
(86.26-375.50)\end{array}$ & $3(100)$ & $\begin{array}{c}157.92 \\
(112.39-307.83)\end{array}$ & $3(75)$ & $\begin{array}{c}39.77 \\
(22.96-46.93)\end{array}$ & 0.688 & 0.259 \\
\hline MIP1 $\beta(n g / L)$ & $\begin{array}{c}7 \\
(100)\end{array}$ & $\begin{array}{c}14.88 \\
(9.31-44.36)\end{array}$ & $\begin{array}{c}11 \\
(100)\end{array}$ & $\begin{array}{c}11.96 \\
(8.69-33.27)\end{array}$ & $3(100)$ & $\begin{array}{c}15.53 \\
(9.87-28.88)\end{array}$ & $4(100)$ & $\begin{array}{c}26.20 \\
(18.91-38.90)\end{array}$ & 0.199 & 0.798 \\
\hline
\end{tabular}


Table 5. Cont

\begin{tabular}{|c|c|c|c|c|c|c|c|c|c|c|}
\hline \multirow[b]{2}{*}{ Immune factor } & \multicolumn{2}{|c|}{$\begin{array}{c}\text { Control Group } \\
(n=7)\end{array}$} & \multicolumn{2}{|c|}{$\begin{array}{l}\text { Colic Group } \\
\quad(n=12)\end{array}$} & \multicolumn{2}{|c|}{$\begin{array}{c}\text { CMPA Group } \\
(n=5)\end{array}$} & \multicolumn{2}{|c|}{$\begin{array}{c}\text { Proctocolitis Group } \\
(n=5)\end{array}$} & \multirow[b]{2}{*}{$p^{*}$} & \multirow[b]{2}{*}{$p^{* *}$} \\
\hline & $\begin{array}{c}n \\
(\%)\end{array}$ & $\begin{array}{l}\text { Median } \\
\text { (IQR) }\end{array}$ & $\begin{array}{c}n \\
(\%)\end{array}$ & $\begin{array}{l}\text { Median } \\
\text { (IQR) }\end{array}$ & $\begin{array}{c}n \\
(\%)\end{array}$ & $\begin{array}{l}\text { Median } \\
\text { (IQR) }\end{array}$ & $\begin{array}{c}n \\
(\%)\end{array}$ & $\begin{array}{l}\text { Median } \\
\text { (IQR) }\end{array}$ & & \\
\hline \multicolumn{11}{|l|}{$\begin{array}{l}\text { Hematopoyetic } \\
\text { factors }\end{array}$} \\
\hline IL5 (ng/L) & $\begin{array}{c}0 \\
(0)\end{array}$ & & $\begin{array}{c}0 \\
(0)\end{array}$ & & $\begin{array}{c}0 \\
(0)\end{array}$ & & $\begin{array}{c}1 \\
(25)\end{array}$ & 1.42 & 0.345 & 0.154 \\
\hline IL7 (ng/L) & $\begin{array}{c}2 \\
(29)\end{array}$ & $\begin{array}{c}5.04 \\
(3.17-6.90)\end{array}$ & $\begin{array}{c}2 \\
(18)\end{array}$ & $\begin{array}{c}13.87 \\
(7.84-19.89)\end{array}$ & $\begin{array}{c}1 \\
(33)\end{array}$ & 15.54 & $\begin{array}{c}1 \\
(25)\end{array}$ & 25.24 & 0.919 & 0.949 \\
\hline GCSF $(\mu \mathrm{g} / \mathrm{L})$ & $\begin{array}{c}3 \\
(43)\end{array}$ & $\begin{array}{c}17.43 \\
(9.90-17.43)\end{array}$ & $\begin{array}{c}0 \\
(0)\end{array}$ & & $\begin{array}{c}3 \\
(100)\end{array}$ & $\begin{array}{c}6.39 \\
(3.56-10.88)\end{array}$ & $\begin{array}{c}2 \\
(50)\end{array}$ & $\begin{array}{c}16.35 \\
(14.80-17.90)\end{array}$ & 0.012 & 0.017 \\
\hline GMCSF ( $\mu \mathrm{g} / \mathrm{L})$ & $\begin{array}{c}3 \\
(43)\end{array}$ & $\begin{array}{c}35.74 \\
(29.11-48.91)\end{array}$ & $\begin{array}{c}3 \\
(27)\end{array}$ & $\begin{array}{c}47.33 \\
(42.44-52.07)\end{array}$ & $\begin{array}{c}2 \\
(67)\end{array}$ & $\begin{array}{c}582.01 \\
(479.61-684.41)\end{array}$ & $\begin{array}{c}2 \\
(50)\end{array}$ & $\begin{array}{c}96.66 \\
(53.01-140.30)\end{array}$ & 0.779 & 0.337 \\
\hline
\end{tabular}

CMPA, Cow's milk protein allergy; GCSF, granulocyte colony-stimulating factor; GMCSF, granulocyte-macrophage colony-stimulating factor; IFN $\gamma$, interferon- $\gamma$; IL, interleukin; MCP1, macrophage-monocyte chemoattractant protein- 1 ; MIP1 $\beta$, macrophage inflammatory protein- $1 \beta$; TNF $\alpha$, tumor necrosis factor- $\alpha . n(\%)$, number (percentage) of samples in which the immunological compound was detected. Concentrations are expressed as median (IQR). * Freeman-Halton extension of the Fisher exact probability test for a $2 \times 4$ contingency table was used to evaluate differences in expression frequencies of the analyzed parameters between groups. ${ }^{* *}$ Kruskal-Wallis tests were used to evaluate differences in the concentration of the different immune factors between groups. 


\subsection{Relationship between the Immune Profile of Milk and Infant Fecal Samples}

Overall, the frequency of detection of all immunological compounds, and in particular those of IL6, IL12, IL2, IL10, IL17, IL5, GCSF and GMCSF, was higher in the infant feces than in milk samples, while the opposite occurred for IL4, IL13, IL8, MCP1, and MIP1 $\beta$ (Supplementary Table S1). Most of the immunological compounds were detected in both types of samples roughly at the same proportion in feces and milk samples between individual study groups with the exception of IL2, IL5, and IL17 that were absent from most milk samples (Table 6). In addition, in the colic group the frequencies of detection in feces for IL6, IL12, IL10, and GCSF were significantly higher than in milk $(p<0.005)$, while the opposite was observed for IL8 and MCP1 ( $p=0.037$ and $p=0.012$, respectively). (Table 6).

Table 6. Frequencies of detection of immunological compounds in milk $(n=25)$ and fecal $(n=28)$ samples in each group of study: control, colic, cow's milk protein allergy (CMPA), and proctocolitis.

\begin{tabular}{|c|c|c|c|c|c|c|c|c|c|c|c|c|}
\hline \multirow[b]{2}{*}{$\begin{array}{l}\text { Immunological } \\
\text { Compound }\end{array}$} & \multicolumn{3}{|c|}{ Control Group } & \multicolumn{3}{|c|}{ Colic Group } & \multicolumn{3}{|c|}{ CMPA Group } & \multicolumn{3}{|c|}{ Proctocolitis Group } \\
\hline & $\begin{array}{l}\text { Milk } \\
(n / N)\end{array}$ & $\begin{array}{l}\text { Feces } \\
(n / N)\end{array}$ & $p^{*}$ & $\begin{array}{l}\text { Milk } \\
(n / N)\end{array}$ & $\begin{array}{l}\text { Feces } \\
(n / N)\end{array}$ & $p^{*}$ & $\begin{array}{l}\text { Milk } \\
(n / N)\end{array}$ & $\begin{array}{l}\text { Feces } \\
(n / N)\end{array}$ & $p^{*}$ & $\begin{array}{l}\text { Milk } \\
(n / N)\end{array}$ & $\begin{array}{l}\text { Feces } \\
(n / N)\end{array}$ & $p^{*}$ \\
\hline IL1 $\beta$ & $6 / 7$ & $6 / 7$ & 1.000 & $6 / 11$ & $11 / 12$ & 0.069 & $2 / 3$ & $3 / 5$ & 1.000 & $4 / 4$ & $4 / 4$ & 1.000 \\
\hline IL6 & $4 / 7$ & $6 / 7$ & 0.559 & $5 / 11$ & $12 / 12$ & 0.005 & $2 / 3$ & $5 / 5$ & 0.375 & $4 / 4$ & $4 / 4$ & 1.000 \\
\hline IL12 & $4 / 7$ & $7 / 7$ & 0.192 & $5 / 11$ & $12 / 12$ & 0.005 & $2 / 3$ & $5 / 5$ & 0.375 & $3 / 4$ & $4 / 4$ & 1.000 \\
\hline \multicolumn{13}{|c|}{ Acquired immunity } \\
\hline IL2 & $0 / 7$ & $7 / 7$ & 0.001 & $0 / 11$ & $12 / 12$ & $<0.001$ & $2 / 3$ & $5 / 5$ & 0.375 & $0 / 4$ & $4 / 4$ & 0.029 \\
\hline IL4 & $3 / 7$ & $1 / 7$ & 0.559 & $1 / 11$ & $0 / 12$ & 0.478 & $2 / 3$ & $0 / 5$ & 0.107 & $3 / 4$ & $0 / 4$ & 0.143 \\
\hline IL10 & $4 / 7$ & $5 / 7$ & 1.000 & $3 / 11$ & $10 / 12$ & 0.012 & $3 / 3$ & $3 / 5$ & 0.464 & $1 / 4$ & $4 / 4$ & 0.143 \\
\hline MCP1 & $6 / 7$ & $3 / 7$ & 0.266 & $8 / 11$ & $2 / 12$ & 0.012 & $3 / 3$ & $0 / 5$ & 0.018 & $3 / 4$ & $1 / 4$ & 0.486 \\
\hline MIP1 $\beta$ & $7 / 7$ & $6 / 7$ & 1.000 & $11 / 11$ & $8 / 12$ & 0.093 & $3 / 3$ & $1 / 5$ & 0.143 & $4 / 4$ & $2 / 4$ & 0.429 \\
\hline \multicolumn{13}{|c|}{ Hematopoyetic factors } \\
\hline IL5 & $0 / 7$ & $7 / 7$ & 0.001 & $0 / 11$ & $12 / 12$ & $<0.001$ & $0 / 3$ & $5 / 5$ & 0.018 & $1 / 4$ & $4 / 4$ & 0.143 \\
\hline IL7 & $2 / 7$ & $5 / 7$ & 0.286 & $2 / 11$ & $5 / 12$ & 0.371 & $1 / 3$ & $1 / 5$ & 1.000 & $1 / 4$ & $1 / 4$ & 1.000 \\
\hline GCSF & $3 / 7$ & $7 / 7$ & 0.070 & $0 / 11$ & $12 / 12$ & $<0.001$ & $3 / 3$ & $3 / 5$ & 0.464 & $2 / 4$ & $3 / 4$ & 1.000 \\
\hline GMCSF & $3 / 7$ & $6 / 7$ & 0.266 & $3 / 11$ & $8 / 12$ & 0.100 & $2 / 3$ & $3 / 5$ & 1.000 & $2 / 4$ & $3 / 4$ & 1.000 \\
\hline
\end{tabular}

GCSF, granulocyte colony-stimulating factor; GMCSF, granulocyte-macrophage colony-stimulating factor; IFN $\gamma$, interferon- $\gamma$; IL, interleukin; MCP1, macrophage-monocyte chemoattractant protein-1; MIP1 $\beta$, macrophage inflammatory protein-1 $\beta$; TNF $\alpha$, tumor necrosis factor- $\alpha . \mathrm{n} / \mathrm{N}$, number of samples in which the immunological compound was detected/total number of samples assayed. ${ }^{*}$ Fisher exact tests were used to evaluate differences in detection frequencies of the analyzed parameters.

There was no clear clustering according to the type of sample (feces or milk) nor to the clinical condition of the immunological profile of fecal and milk samples, according to the presence or absence of the immunological compounds (Supplementary Figure S1).

\section{Discussion}

In this pilot study, we evaluated the microbiological and immunological profiles of samples of feces and milk obtained from mother-infant pairs in which the respective breastfed infants were suffering from different gastrointestinal disorders. Intestinal microbiota plays a key role in the host metabolism and in the maturation and education of the immune system [24]. Several studies have assessed the fecal microbiota in infants with different gastrointestinal disorders (colic, food allergy and/or food hypersensitivity), and all of them postulated an association between these conditions and a gut dysbiosis state [11-13,15].

Bifidobacterium is considered as the dominant bacterial genera in the infant gut microbiome of breastfed infants [25,26]; in our study, the abundance of Bifidobacterium DNA in the feces of CMPA 
infants was lower than that observed in the other groups. A reduced presence of bifidobacteria in fecal samples from infants suffering CMPA has already been reported [11,27]. This finding might be related to the type of delivery. Most of the infants in CMPA group were born by Cesarean section, which has been related to lower Bifidobacterium content due, at least in part, to delayed initiation of breastfeeding [28]. Moreover, in this study fecal samples of CMPA infants were also characterized by a higher abundance of the genus Rothia and the families Lachnospiraceae, Peptostreptococcaceae and Eggerthellaceae. Lachnospiraceae and Peptostreptococcaceae have been previously reported to be enriched in the gut microbiota of CMPA infants, but the significance of their presence remains unclear [15,26,29-33]. Remarkably, Eggerthellaceae was more abundant in the milk of mothers of CMPA infants. Eggerthellaceae is an emerging bacterial family that has been associated to gastrointestinal and genitourinary pathologies and some members of this family are characterized by their ability to spread from these locations to blood [34,35], a fact that would explain their presence in milk samples. Unfortunately, maternal fecal samples were not available in this study and, therefore, we could not assess potential mother-to-infant transfer of members of this family.

In our study, bacterial diversity was higher among the feces of CMPA infants than among those from healthy controls. This result is in agreement with that of a previous study which reported an increased microbial diversity in children with milk allergy in comparison to healthy ones [15]. In contrast, other authors [13] found a reduced diversity of the early intestinal microbiota of infants with allergic diseases using DNA fingerprinting techniques, which can only detect bacteria with a relative abundance of $>1 \%$. Globally, our results showed that infants with CMPA present a peculiar fecal microbial profile, which is different from that of the other groups of infants included in this study (colic, proctocolitis, and healthy). However, no statistically significant differences were found among the later groups despite previous studies had reported the existence of a bacterial dysbiosis and a reduced microbial diversity in the feces of infants suffering from lactational colic [6,36-38].

Breast milk contains immunologically active compounds that provide a protective effect for CMPA in children at high risk $[25,39]$, being one of the main drivers in determining the microbiome composition of the infant gut $[17,25,40]$. Unfortunately, studies addressing the mechanisms enabling human milk to reduce the allergic disease risk are very scarce [41].

The immature gastrointestinal barrier in newborns is ineffective to prevent intact ingested food antigens from stimulating the immune system. These antigens permeate the intestinal wall inducing an immune response [14]. Moreover, bacterial dysbiosis predisposes the neonatal intestine to inflammation [42]. For this reason, a wide range of cytokines, chemokines, growth factors and immunoglobulins were determined in the fecal and milk samples in order to characterize their immunological profiles and their possible relation with bacterial colonization. Our study did not reveal notorious changes in either the frequency of detection or the concentration of the immunological factors in feces, except for a lower frequency of detection of GCSF in fecal samples of infants with CMPA and proctocolitis. This growth-stimulating factor is released when there is a bacterial infection to increase the maturation of neutrophils [43]. In addition, IL7 concentration was lower in samples of infants with colics in comparison to those from the control group. IL7 is a non-hematopoietic cell-derived cytokine with a crucial role in the adaptive immune system and for B and $\mathrm{T}$ cell development and may serve as a regulatory factor for intestinal mucosal lymphocytes [44]. Another immunological feature of fecal samples from infants with proctocolitis was a reduced content of IL10. IL10 suppresses both the innate and adaptative responses of the immune system, and limits the inflammatory responses [45]. Thus, reduced fecal IL10 could explain bleeding related to gut inflammation in the Proctocolitis group.

In contrast with the fecal samples, milk samples showed variations among the four study groups in the immunological factors related to acquired immunity. IL2, which plays an important role in balancing the immune response [46], was only detected in CMPA group. Besides, anti-inflammatory IL10 and pro-inflammatory IL17 and GMCSF were also more abundant in milk from CMPA group in comparison with the rest of the groups. IL10 in human milk seems to provide some degree of protection against CMPA although this relation is unclear [25,47]. On the other hand, IL17 is considered 
to play an important role on the inflammatory process, but its role (and that of IL17-producing cells) during allergic inflammation remains unknown [48]. IL13 abundance was lower in the milk of mothers whose children suffered from lactational colic. This cytokine has been recently recognized for its novel role in allergic and other inflammatory diseases, being released by signals from an inflamed gut epithelium [49]. Recent studies have shown that selected bacterial species and their metabolites (such as short-chain fatty acids) may positively modulate immune tolerance mechanisms [33]. Although some studies have postulated a possible association between allergy and an altered microbiota pattern [11], the gut microbiota of infants suffering non-IgE-mediated CMPA remains uncharacterized [30], partly because of the difficulty in establishing an unambiguous diagnosis [31].

The most important limitation in this pilot study is the low size of the cohort sample, which is mainly related to the in practice difficulties in a proper differential diagnosis among the gastrointestinal disorders included in this study. However, we identified a few microbial signatures in feces that may explain part of the difference between CMPA and other infants. We also detected some milk immunological signatures among the different conditions addressed in this study. Their usefulness as biomarkers should be tested in further studies involving a much larger population.

\section{Conclusions}

This study provides preliminary data on the fecal microbiological and immunological profile of gastrointestinal disorders in infants, including colic, CMPA and proctocolitis, and their relation to the microbiological and immunological profile of maternal milk. Only infants in the CMPA group displayed significant variations in the composition of the fecal microbiome, specifically of the family (Eggerthellaceae, Lachnospiraceae and Peptostreptococcaceae) and genus (Bifidobacterium, Rothia) taxonomic levels. In addition, there was a higher content of Eggerthellaceae in mother's milk in infants with CMPA. The immunological profile of milk samples of CMPA group was also distinct with regards to all immunological compounds related to the acquired immunity assayed in this study (IL2, IL4, IL10, IL13, and IL17). Higher concentrations in milk of this set of cytokines compared to other groups could favor excessive inflammation in the gut.

Supplementary Materials: The following are available online at http://www.mdpi.com/2072-6643/12/3/634/s1, Figure S1: Cluster heatmap of the immunological factors present in the fecal and milk samples $(n=34)$ from the different participants included in the study, Table S1: Global comparison of the frequencies of detection of immunological compounds in milk $(n=25)$ and fecal $(n=28)$ samples.

Author Contributions: Conceptualization, J.M.R., L.F. and P.S.G.C.A.M.P.H.A.6; formal analysis, M.A., C.A. and L.F.; investigation, M.A., C.A. and P.S.G.C.A.M.P.H.A.6; resources, J.M.R., L.F. and P.S.G.C.A.M.P.H.A.6; data curation, M.A., C.A. and P.S.G.C.A.M.P.H.A.6; writing-original draft preparation, M.A.; writing-review and editing, J.M.R. and L.F.; visualization, M.A., C.A. and L.F.; project administration, J.M.R.; funding acquisition, J.M.R. and L.F. All authors have read and agreed to the published version of the manuscript.

Funding: This research was funded by Spanish Ministry of Economy and Competitiveness; grant number AGL2016-75476-R.

Acknowledgments: We would like to thank Susana Manzano (Probisearch) for her help in the logistic aspects of the study, and also to all of the study participants.

Conflicts of Interest: The authors declare no conflict of interest. The funders had no role in the design of the study; in the collection, analyses, or interpretation of data; in the writing of the manuscript, or in the decision to publish the results.

\section{References}

1. Benninga, M.A.; Nurko, S.; Faure, C.; Hyman, P.E.; St James Roberts, I.; Schechter, N.L. Childhood functional gastrointestinal disorders: Neonate/toddler. Gastroenterology 2016, 150, 1443-1455.e2. [CrossRef]

2. Mahon, J.; Lifschitz, C.; Ludwig, T.; Thapar, N.; Glanville, J.; Miqdady, M.; Saps, M.; Quak, S.H.; Lenoir Wijnkoop, I.; Edwards, M.; et al. The costs of functional gastrointestinal disorders and related signs and symptoms in infants: A systematic literature review and cost calculation for England. BMJ Open 2017, 7, e015594. [CrossRef] 
3. Hyman, P.E.; Milla, P.J.; Benninga, M.A.; Davidson, G.P.; Fleisher, D.F.; Taminiau, J. Childhood functional gastrointestinal disorders: Neonate/toddler. Gastroenterology 2006, 130, 1519-1526. [CrossRef] [PubMed]

4. Caubet, J.C.; Szajewska, H.; Shamir, R.; Nowak-Wegrzyn, A. Non-IgE-mediated gastrointestinal food allergies in children. Pediatr. Allergy Immunol. 2017, 28, 6-17. [CrossRef] [PubMed]

5. Sung, V.; Hiscock, H.; Tang, M.; Mensah, F.K.; Heine, R.G.; Stock, A.; York, E.; Barr, R.G.; Wake, M. Probiotics to improve outcomes of colic in the community: Protocol for the Baby Biotics randomised controlled trial. BMC Pediatr. 2012, 12, 135. [CrossRef] [PubMed]

6. Dubois, N.E.; Gregory, K.E. Characterizing the intestinal microbiome in infantile colic: Findings based on an integrative review of the literature. Biol. Res. Nurs. 2016, 18, 307-315. [CrossRef]

7. Pensabene, L.; Salvatore, S.; D'Auria, E.; Parisi, F.; Concolino, D.; Borrelli, O.; Thapar, N.; Staiano, A.; Vandenplas, Y.; Saps, M. Cow's milk protein allergy in infancy: A risk factor for functional gastrointestinal disorders in children? Nutrients 2018, 10, 1716. [CrossRef]

8. Mousan, G.; Kamat, D. Cow's milk protein allergy. Clin. Pediatr. 2016, 55, 1054-1063. [CrossRef]

9. Tsabouri, S.; Nicolaou, N.; Douros, K.; Papadopoulou, A.; Priftis, K. Food protein induced proctocolitis: A benign condition with an obscure immunologic mechanism. Endocr. Metab. Immune Disord. Drug Targets 2017, 17, 32-37. [CrossRef]

10. Vandenplas, Y.; Benninga, M.A.; Broekaert, I.J.; Falconer, J.; Gottrand, F.; Guarino, A.; Lifschitz, C.; Lionetti, P.; Orel, R.; Papadopoulou, A.; et al. Functional gastro-intestinal disorder algorithms focus on early recognition, parental reassurance and nutritional strategies. Acta Paediatr. 2016, 105, 244-252. [CrossRef]

11. Dong, P.; Feng, J.J.; Yan, D.Y.; Lyu, Y.J.; Xu, X. Early-life gut microbiome and cow's milk allergy- a prospective case - control 6-month follow-up study. Saudi J. Biol. Sci. 2018, 25, 875-880. [CrossRef] [PubMed]

12. Chau, K.; Lau, E.; Greenberg, S.; Jacobson, S.; Yazdani-Brojeni, P.; Verma, N.; Koren, G. Probiotics for infantile colic: A randomized, double-blind, placebo-controlled trial investigating Lactobacillus reuteri DSM 17938. J. Pediatr. 2015, 166, 74-78. [CrossRef] [PubMed]

13. Ling, Z.; Li, Z.; Liu, X.; Cheng, Y.; Luo, Y.; Tong, X.; Yuan, L.; Wang, Y.; Sun, J.; Li, L.; et al. Altered fecal microbiota composition associated with food allergy in infants. Appl. Environ. Microbiol. 2014, 80, $2546-2554$. [CrossRef]

14. Fahey, L.M.; Liacouras, C.A. Eosinophilic gastrointestinal disorders. Pediatr. Clin. N. Am. 2017, 64, 475-485. [CrossRef] [PubMed]

15. Huang, Y.J.; Marsland, B.J.; Bunyavanich, S.; O’Mahony, L.; Leung, D.Y.; Muraro, A.; Fleisher, T.A. The microbiome in allergic disease: Current understanding and future opportunities-2017 PRACTALL document of the American Academy of Allergy, Asthma and Immunology and the European Academy of Allergy and Clinical Immunology. J. Allergy Clin. Immunol. 2017, 139, 1099-1110. [CrossRef] [PubMed]

16. Fernández, L.; Langa, S.; Martín, V.; Maldonado, A.; Jiménez, E.; Martín, R.; Rodríguez, J.M. The human milk microbiota: Origin and potential roles in health and disease. Pharmacol. Res. 2013, 69, 1-10. [CrossRef]

17. Bäckhed, F.; Roswall, J.; Peng, Y.; Feng, Q.; Jia, H.; Kovatcheva-Datchary, P.; Li, Y.; Xia, Y.; Xie, H.; Zhong, H.; et al. Dynamics and stabilization of the human gut microbiome during the first year of life. Cell Host Microbe 2015, 17, 690-703. [CrossRef]

18. Lackey, K.A.; Williams, J.E.; Meehan, C.L.; Zachek, J.A.; Benda, E.D.; Price, W.J.; Foster, J.A.; Sellen, D.W.; Kamau-Mbuthia, E.W.; Kamundia, E.W.; et al. What's normal? Microbiomes in human milk and infant feces are related to each other but vary geographically: The INSPIRE Study. Front. Nutr. 2019, 6, 45. [CrossRef]

19. Klindworth, A.; Pruesse, E.; Schweer, T.; Peplies, J.; Quast, C.; Horn, M.; Glöckner, F.O. Evaluation of general $16 \mathrm{~S}$ ribosomal RNA gene PCR primers for classical and next-generation sequencing-based diversity studies. Nucleic Acids Res. 2013, 41, e1. [CrossRef]

20. Caporaso, J.G.; Kuczynski, J.; Stombaugh, J.; Bittinger, K.; Bushman, F.D.; Costello, E.K.; Fierer, N.; Peña, A.G.; Goodrich, J.K.; Gordon, J.I.; et al. QIIME allows analysis of high throughput community sequencing data. Nat. Methods 2010, 7, 335-336. [CrossRef]

21. Zakrzewski, M.; Proietti, C.; Ellis, J.J.; Hasan, S.; Brion, M.J.; Berger, B.; Krause, L. Calypso: A user-friendly web-server for mining and visualizing microbiome-environment interactions. Bioinformatics 2017, 33, 782-783. [CrossRef] [PubMed]

22. Yilmaz, P.; Parfrey, L.W.; Yarza, P.; Gerken, J.; Pruesse, E.; Quast, C.; Schweer, T.; Peplies, J.; Ludwig, W.; Glöckner, F.O. The SILVA and "All-species Living Tree Project (LTP)" taxonomic frameworks. Nucleic Acids Res. 2014, 42, D643-D648. [CrossRef] [PubMed] 
23. Espinosa-Martos, I.; Montilla, A.; de Segura, A.G.; Escuder, D.; Bustos, G.; Pallás, C.; Rodríguez, J.M.; Corzo, N.; Fernández, L. Bacteriological, biochemical, and immunological modifications in human colostrum after Holder pasteurisation. J. Pediatr. Gastroenterol. Nutr. 2013, 56, 560-568. [CrossRef] [PubMed]

24. Belkaid, Y.; Harrison, O.J. Homeostatic immunity and the microbiota. Immunity 2017, 46, 562-576. [CrossRef]

25. Rajani, P.S.; Seppo, A.E.; Jarvinen, K.M. Immunologically active components in human milk and development of atopic disease, with emphasis on food allergy, in the pediatric population. Front. Pediatr. 2018, 6, 218. [CrossRef]

26. Sagheddu, V.; Patrone, V.; Miragoli, F.; Puglisi, E.; Morelli, L. Infant early gut colonization by Lachnospiraceae: High frequency of Ruminococcus gnavus. Front. Pediatr. 2016, 4, 57. [CrossRef]

27. Thompson-Chagoyan, O.C.; Vieites, J.M.; Maldonado, J.; Edwards, C.; Gil, A. Changes in fecal microbiota of infants with cow's milk protein allergy - a Spanish prospective case-control 6-month follow-up study. Pediatr. Allergy Immunol. 2010, 21, e394-e400. [CrossRef]

28. Werlang, I.; Mueller, N.T.; Pizoni, A.; Wisintainer, H.; Matte, U.; Costa, S.; Ramos, J.; Goldani, M.Z.; Dominguez-Bello, M.G.; Goldani, H. Associations of birth mode with cord blood cytokines, white bloodcells, and newborn intestinal bifidobacteria. PLOS ONE 2018, 13, e0205962. [CrossRef]

29. Berni Canani, R.; Sangwan, N.; Stefka, A.T.; Nocerino, R.; Paparo, L.; Aitoro, R.; Calignano, A.; Khan, A.A.; Gilbert, J.A.; Nagler, C.R. Lactobacillus rhamnosus GG-supplemented formula expands butyrate-producing bacterial strains in food allergic infants. ISME J. 2016, 10, 742-750. [CrossRef]

30. Berni Canani, R.; De Filippis, F.; Nocerino, R.; Paparo, L.; Di Scala, C.; Cosenza, L.; Della Gatta, G.; Calignano, A.; De Caro, C.; Laiola, M.; et al. Gut microbiota composition and butyrate production in children affected by non-IgE-mediated cow's milk allergy. Sci. Rep. 2018, 8, 12500. [CrossRef]

31. Diaz, M.; Guadamuro, L.; Espinosa-Martos, I.; Mancabelli, L.; Jimenez, S.; Molinos-Norniella, C.; Perez-Solis, D.; Milani, C.; Rodriguez, J.M.; Ventura, M.; et al. Microbiota and derived parameters in fecal samples of infants with non-IgE cow's milk protein allergy under a restricted diet. Nutrients 2018, 10, 1481. [CrossRef] [PubMed]

32. Feehley, T.; Plunkett, C.H.; Bao, R.; Choi Hong, S.M.; Culleen, E.; Belda-Ferre, P.; Campbell, E.; Aitoro, R.; Nocerino, R.; Paparo, L.; et al. Healthy infants harbor intestinal bacteria that protect against food allergy. Nat. Med. 2019, 25, 448-453. [CrossRef] [PubMed]

33. Iozzo, P.; Sanguinetti, E. Early dietary patterns and microbiota development: Still a way to go from descriptive interactions to health-relevant solutions. Front. Nutr. 2018, 5, 5. [CrossRef] [PubMed]

34. Gardiner, B.J.; Tai, A.Y.; Kotsanas, D.; Francis, M.J.; Roberts, S.A.; Ballard, S.A.; Junckerstorff, R.K.; Korman, T.M. Clinical and microbiological characteristics of Eggerthella lenta bacteremia. J. Clin. Microbiol. 2015, 53, 626-635. [CrossRef] [PubMed]

35. Lau, S.K.; Woo, P.C.; Fung, A.M.; Chan, K.M.; Woo, G.K.; Yuen, K.Y. Anaerobic, non-sporulating, Gram-positive bacilli bacteraemia characterized by $16 \mathrm{~S}$ rRNA gene sequencing. J. Med. Microbiol. 2004, 53 Pt 12, 1247-1253. [CrossRef]

36. Lehtonen, L.; Korvenranta, H.; Eerola, E. Intestinal microflora in colicky and noncolicky infants: Bacterial cultures and gas-liquid chromatography. J. Pediatr. Gastroenterol. Nutr. 1994, 19, 310-314. [CrossRef]

37. Savino, F.; Cresi, F.; Pautasso, S.; Palumeri, E.; Tullio, V.; Roana, J.; Silvestro, L.; Oggero, R. Intestinal microflora in breastfed colicky and non-colicky infants. Acta Paediatr. 2004, 93, 825-829. [CrossRef]

38. Savino, F.; Bailo, E.; Oggero, R.; Tullio, V.; Roana, J.; Carlone, N.; Cuffini, A.M.; Silvestro, L. Bacterial counts of intestinal Lactobacillus species in infants with colic. Pediatr. Allergy Immunol. 2005, 16, 72-75. [CrossRef]

39. Muraro, A.; Halken, S.; Arshad, S.H.; Beyer, K.; Dubois, A.E.J.; Du Toit, G.; Eigenmann, P.A.; Grimshaw, K.E.; Hoest, A.; Lack, G.; et al. EAACI Food Allergy and Anaphylaxis Guidelines Group. EAACI food allergy and anaphylaxis guidelines. Primary prevention of food allergy. Allergy 2014, 69, 590-601. [CrossRef]

40. Milani, C.; Duranti, S.; Bottacini, F.; Casey, E.; Turroni, F.; Mahony, J.; Belzer, C.; Delgado Palacio, S.; Arboleya Montes, S.; Mancabelli, L.; et al. The first microbial colonizers of the human gut: Composition, activities, and health implications of the infant gut microbiota. Microbiol. Mol. Biol. Rev. 2017, 81, e00036-17. [CrossRef]

41. Lodge, C.J.; Tan, D.J.; Lau, M.X.; Dai, X.; Tham, R.; Lowe, A.J.; Bowatte, G.; Allen, K.J.; Dharmage, S.C. Breastfeeding and asthma and allergies: A systematic review and meta-analysis. Acta Paediatr. 2015, 104, 38-53. [CrossRef] [PubMed] 
42. Gomez, M.; Moles, L.; Espinosa-Martos, I.; Bustos, G.; de Vos, W.M.; Fernandez, L.; Rodriguez, J.M.; Fuentes, S.; Jimenez, E. Bacteriological and immunological profiling of meconium and fecal samples from preterm infants: A two-year follow-up study. Nutrients 2017, 9, 1293. [CrossRef] [PubMed]

43. Eyles, J.L.; Roberts, A.W.; Metcalf, D.; Wicks, I.P. Granulocyte colony-stimulating factor and neutrophilsforgotten mediators of inflammatory disease. Nat. Clin. Pract. Rheumatol. 2006, 2, 500-510. [CrossRef] [PubMed]

44. Gao, J.; Zhao, L.; Wan, Y.Y.; Zhu, B. Mechanism of action of IL-7 and its potential applications and limitations in cancer immunotherapy. Int. J. Mol. Sci. 2015, 16, 10267-10280. [CrossRef]

45. Iyer, S.S.; Cheng, G. Role of interleukin 10 transcriptional regulation in inflammation and autoimmune disease. Crit. Rev. Immunol. 2012, 32, 23-63. [CrossRef]

46. Waters, R.S.; Perry, J.S.A.; Han, S.; Bielekova, B.; Gedeon, T. The effects of interleukin-2 on immune response regulation. Math. Med. Biol. 2018, 35, 79-119. [CrossRef]

47. Jarvinen, K.M.; Suarez-Farinas, M.; Savilahti, E.; Sampson, H.A.; Berin, M.C. Immune factors in breast milk related to infant milk allergy are independent of maternal atopy. J. Allergy Clin. Immunol. 2015, 135, 1390-1393.e6. [CrossRef]

48. Kuwabara, T.; Ishikawa, F.; Kondo, M.; Kakiuchi, T. The role of IL-17 and related cytokines in inflammatory autoimmune diseases. Mediat. Inflamm. 2017, 2017, 3908061. [CrossRef]

49. Mannon, P.; Reinisch, W. Interleukin 13 and its role in gut defence and inflammation. Gut 2012, 61, $1765-1773$. [CrossRef]

(C) 2020 by the authors. Licensee MDPI, Basel, Switzerland. This article is an open access article distributed under the terms and conditions of the Creative Commons Attribution (CC BY) license (http://creativecommons.org/licenses/by/4.0/). 